\title{
HINDU BELIEFS AND THE MARITIME NETWORK IN SOUTHERN VIETNAM DURING THE EARLY COMMON ERA
}

\author{
Le Thi Lien
}

\author{
Institute of Archaeology, Hanoi, Vietnam \\ lelienthi10@gmail.com \\ Key words: Southeast Asia, maritime network, Southern Vietnam, Oc Eo culture, Hindu belief
}

\begin{abstract}
In recent decades many artefacts related to ancient Hindu belief have been discovered in southern Vietnam; in addition to those unearthed from other sites in Southeast Asia. These artefacts have been found at various types of archaeological site and clearly played different functions in the religious beliefs and daily lives of the people. This essay will make a comparative analysis of the Vietnamese archaeological resource within the broader regional context in order to better understand the history of the penetration of Hinduism into Southeast Asia. The following subjects will be addressed: typical sites that exposed evidence of Hindu rites and practices, characteristics of artefacts that represent the propagation and extension of Hindu belief and practices in southern Vietnam, the role of maritime trading networks in the propagation of Hindu beliefs and the formation of the first state in southern Vietnam during the early $1^{\text {st }}$ millennium $A D$.
\end{abstract}

\section{INTRODUCTION}

The study of ancient Hinduism in Southeast Asia, as with Buddhism, has traditionally been art historically and architecturally focused (e.g. Dupont 1941; 1955; Krairish 1980). It is noteworthy that most of the works on Hindu art are based on sculptures and inscriptions dating from the mid- $1^{\text {st }}$ millennium $\mathrm{AD}$, with the earliest evidence of Vișnu images found from the so-called coastal city-states and therefore considered as playing a major role in state formation processes during the $5^{\text {th }}$ to $7^{\text {th }}$ centuries(e.g. Manguin 2004; Lavy2014). While artefacts related to the Indian Buddhist world have been identified from several early archaeological sites, Hindu symbols are scarcely referred to in some research works (Glover and Bellina 2011; Le 2005, 2006a). Manguin (2010), in his discussion of pan-regional responses to South Asian inputs in early Southeast Asia, assumed that art historians have long been aware that early Southeast Asian cultures shared a common vocabulary of style in representing divinities. This was not a sudden imposition of Indian culture from the $3^{\text {rd }}$ century AD but the result of a long period during which people travelled back and forth in the broad cultural interaction sphere. Questions on the coexistence or ri- valry of Buddhism and Hinduism, and the role of Vismu and 'Siva in the political scene of the early Southeast Asian state have also been discussed (Lavy 2003, Guy 2014: 8-9). Himanshu Prabha Ray (2014: 136) recently went further to emphasize the plurality, diversity and coexistence of numerous religious traditions at the beginning of the $1^{\text {st }}$ millennium AD by analyzing inscriptions, sculptures and archaeological data from pre-modern Thailand and India. Lavy (2014: 170) recognized that the fully developed mitred Vișmu tradition of the late $6^{\text {th }}$ - early $7^{\text {th }}$ centuries AD was a localized and largely "internal" Southeast Asian innovation. In my previous work I have noted Hindu arts and symbols from both temple architectural and other archaeological contexts in southern Vietnam (Le 2002, 2005; Le and Witzel 2008). The tendency towards localization can be observed even from the tiny religious emblems from earlier periods (Le 2011a). However, we can still see only a blurred picture of regional non-élite religious practices.

During the time period concerned (c. $1^{\text {st }}$ century BC to c. $8^{\text {th }}$ century AD), archaeological data, including those related to religious emblems, have been found from sites that played important roles as entrepôts, coastal settlements and burial-grounds in Southeast Asia. This indicates that Hindu and other beliefs penetrated southern Vietnam and other parts of Southeast Asia via trading networks, mainly sea routes. From the first half of the $1^{\text {st }}$ millennium $\mathrm{AD}$, several sites developed as political and religious centers, which contributed greatly to the formation of early states in Southeast Asia. In southern Vietnam, in addition to large number of archaeological sites and artefacts found by French scholars, evidence of the so-called Oc Eo culture were unearthed in abundance from the late $19^{\text {th }}$ century (Malleret 1959; 1963; Le et. al. 1995; Manguin 2002; 2009; Vo 2003). The available archaeological data support the argument that southern Vietnam was an important part of Funan $\left(2^{\text {nd }}-7^{\text {th }} c . A D\right.$, see Pelliot 1903; Miksic 2003). Various artefact classes are useful sources for studying the social life of local people, including their religious practices. Recently, the excavation of archaeological sites datable to the pre-Oc Eo period also brought to light data on the beliefs of the local people during the last centuries BC (Tran et. al. 1999; Tran, Lai 2007). 


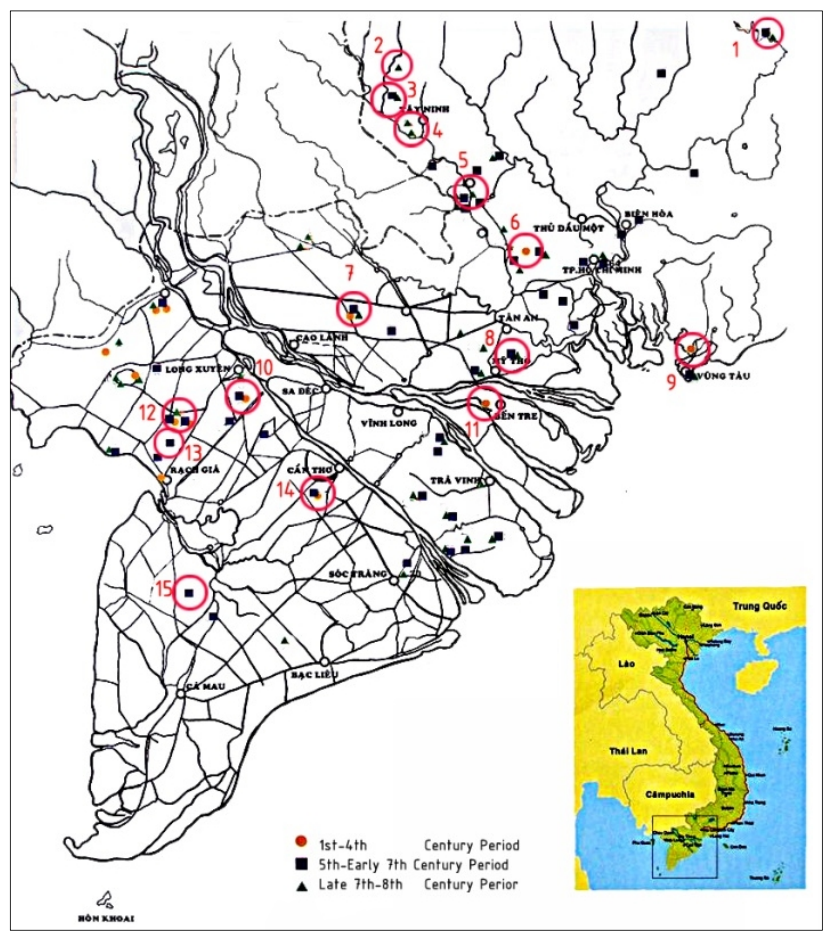

Figure 1: Map of Hindu site and artefact distribution. Main sites referred to in the text: 1-Cat Tien (Lam Dong); 2 - Chot Mat; 3Go Mieu; 4- Co Lam tu; 5- Binh Thanh (Tay Ninh); 6- Go Cao Su (Long An); 7- Go Thap (Dong Thap); 8- Go Thanh (Tien Giang); 9- Giong Lon (Ba Ria-Vung Tau); 10- Da Noi (An Giang); 11- Giong Noi (Ben Tre); 12-Oc Eo-Ba The (An Giang); 13- Nen Chua (Kien Giang); 14 - Nhon Thanh (Can Tho); 15- Ke Mot (Kien Giang).

In Funan's broader context, research on the early history of Cambodia and other Southeast Asian regions also provide data on religious practices, Hinduism in particular. In the same context of the lower Mekong river delta of southern Cambodia, in addition to various works on pre-Angkorian art and history, new archaeological discoveries shed new light on the deep roots of socio political complexity in mainland Southeast Asia. Particularly valuable data has been unearthed by members of the Lower Mekong Archaeological Project at Angkor Borei, a site that has been associated with Funan and its capital (Stark 1998, 2001, 2003, 2004, 2006; Stark et. al. 2006). In this regard, this paper will attempt to survey archaeological sources on the cultural interaction and religious life of people in this area.

\section{DISCOVERY OF SITES AND ARTEFACTS RELATED TO HINDU BELIEF}

From Chinese literature it is well-known that both Hindu and Buddhist beliefs were practiced by the people of Funan (Pelliot 1903). In 1819, Trinh Hoai Duc was the first Vietnamese who wrote on the discovery of gold plaques incised with images of monsters riding on elephants among the bricks and tiles in the Gia Dinh area (present Ho Chi Minh city) (Trịnh 1998: 32). By the end of the $19^{\text {th }}$ century and the beginning of the $20^{\text {th }}$ century, a large number of artefacts and sites had been found by French scholars. It is noteworthy that most of these artefacts were found by chance and that some sculptures were moved from their original places. Although traces of many brick structures were noted, the French could excavate only the Oc Eo site (Malleret 1959).

Since 1975, archaeological explorations and excavations in southern Vietnam have brought to light larger numbers of artefacts and sites, including those found with preserved contexts. They provide information on the development of Hinduism in the area. Typical sites that exposed evidence of Hindu belief are examined of three main types: temple architectural complexes, grave sites and settlement sites (Figure 1).

\section{Temple architectural complexes}

The most important and clearly identified site is the Cat Tien temple complex (Lam Dong province). The architectural style corresponds to a long time bracket, from the end of the $6^{\text {th }}$ century to the $9^{\text {th }}$ century (Le 2006: 248255; Nguyen 2002). From evidence of inscription and art, the dates of some architectural remains are identified from the late $7^{\text {th }}$ to late $8^{\text {th }}$ centuries AD. The rich consecrated deposits found from the foundation of these temples also indicate that the Garbhanyāsa ceremony for the construction of a Hindu temple was practiced following the Hindu custom (Ślączka 2007: 176-78). However, it was modified greatly from case to case in the same complex. In temple 1a, the largest (Figure 2), many artefacts were unearthed in the central hollow brick shaft, including 166 gold artefacts, 4 gold lingas, a silver egg-like vase containing a bronze linga plated with silver, 1 piece of tin, 6 fragments of color stones (Le 2006: 49). 25 pieces among the gold plagues were inscribed with images of the main gods and goddesses of Hindu pantheon, such as 'Siva as Mahe'svara, 'Siva with Pārvatī and Bhū, Vișnu on Garuda, Brahmā on lotus base, Sürya on the cart driving by the horse, Kubera, Lakșmī, and the Așta-Dikpāla etc. 37 others were inscribed, mainly with prayers and the name of the donor.

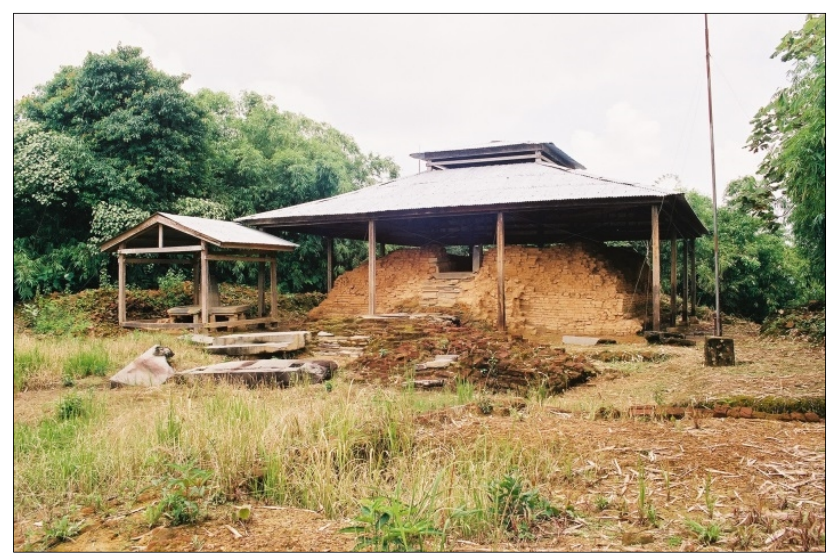

Figure 2: Temple 1A, Cat Tien site

In architectural remain of temple $6 \mathrm{~B}$, of 20 gold plaque fragments found from the central brick shaft under the foundation, 10 are inscribed with the names of the 
Dikpala, Brahmā and the Vedi the sacrificial altar (Witzel\& Le 2007; Le 2011a).

The discovery of Cat Tien site thus reconfirms the opinion that many architectural remains unearthed in the lower delta of the Mekong River functioned as temples rather than the graves (Le 2005; 2006a: 148-154; Slączka 2011). Rich consecrated deposits were also found in the central hollowed brick shafts of seven architectural remains at Da Noi site (An Giang province), including the gold plaques inscribed with the symbols of Hindu gods, images of Vispu, the worshipers and inscriptions. In case of architectural remain 85.DN.M2, the gold plaques were scattering around two bronze bowls containing a gold linga-yoni. A precious stone was also found (Le et. al. 1995: 232-241). Several temple architectural remains were identified at the Go Thap site complex (Dong Thap province) but the central part of their foundation was looted (Le et. al. 1995: 180-186). In the so called Grave Mound, architectural remains were found and identified by the excavators as graves (Dao 1995; Le et. al. 1995: 243-250). The analysis of the artefacts found from the central hollow brick shafts of the foundations make it possible to identify some of them as remains of the Hindu temples, which were built at different times in the first half of the $1^{\text {st }}$ millennium AD (Le 2005a: 150-152) (Figure 3).

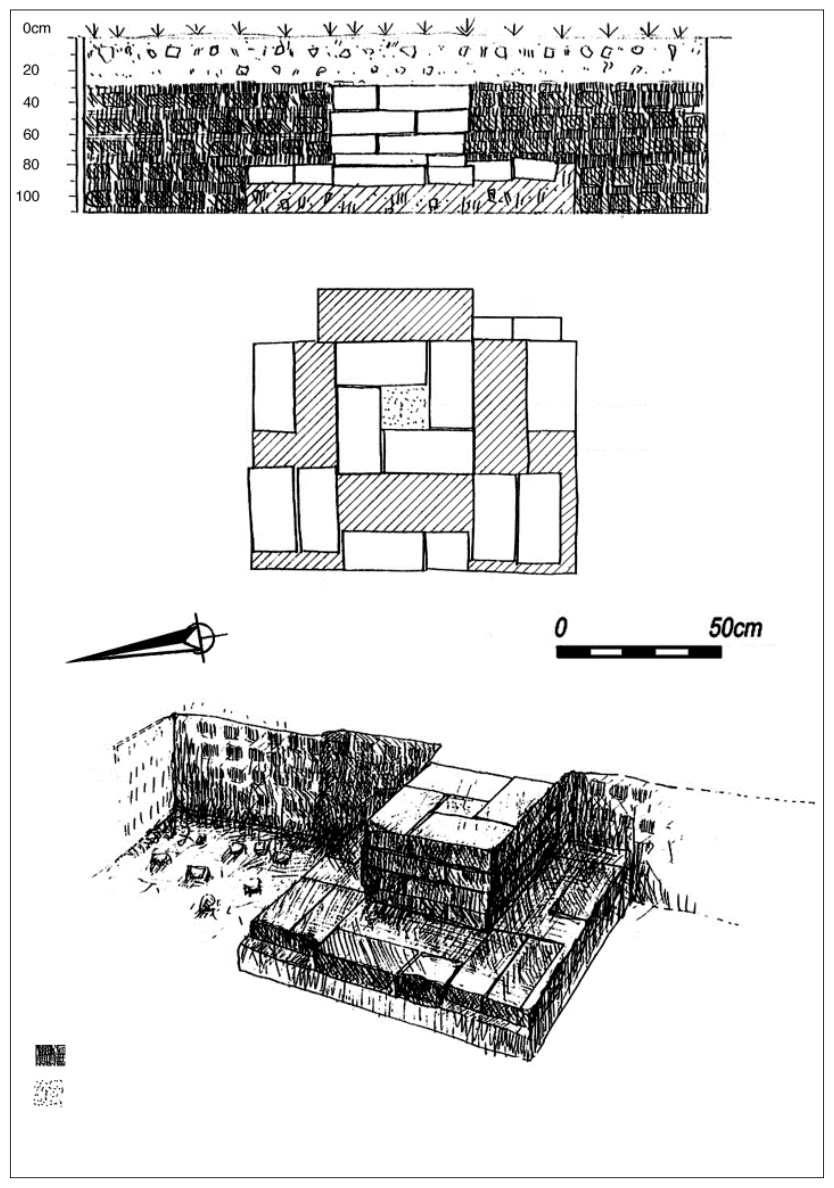

Figure 3: Central brick structure of temple foundation GT93M1, Go Thap (Drawing by Bui Xuan Long)
Several architectural remains from Nen Chua and $\mathrm{Ke}$ Mot sites (Kien Giang province), Go Thanh site (Tien Giang province) were built for the same function (Le 2006a: 152-156). In addition, a large number of sculptures and fragments of Viș̣u images, 'Sivalinga, linga-yoni, yonis, natural stones (except the tiny lingas), images of other Hindu gods and goddesses are unearthed from hundreds of sites in southern Vietnam. They indicate that Hindu practice was in vogue and several types of temples could have been built from the $1^{\text {st }} \mathrm{c}$.AD and spreading in the region during the heyday of Oc Eo culture $\left(5^{\text {th }}-6^{\text {th }}\right.$ centuries AD). Temples continued to be built at some sites in later periods (Le 2006a: 186, Table 2.2, 2.3).

\section{Grave sites}

It is difficult to identify clear evidence of Hindu funeral ceremonies in archaeological sites. Many brick and granite structures have been identified as cremated burial. This type of site has a central brick block having a square hollow filled with sand and other objects, such as gold plaques, precious stones or beads. Several sites containing rich assemblages of artefacts have been identified as temple architecture, as discussed above. There are other sites which have similar structure in Oc Eo city (such as the so called graves OE83.A1, OE83.A3, OE83.A3', OE83.GD1). However, due to the lack of clear indicators, their function is unknown. Some researcher suggest that they could have been the grave or sepulcher of the elite (Le et. al. 1995: 227-229; 269-270; Le 2006a: 155).The first cremated jar burial was unearthed from Linh Son 1 site on the slope of mount $\mathrm{Ba}$ The. The excavations during 2001-2003 at the Minh $\mathrm{Su}$ mound settlement cum burial site (Go Thap) provides rich evidence of at least 24 burials and traces of several others. Go Thap site thus provides the most interesting information on the custom of burial ceremony of those who were common ordinary people. Three types of burial practices are unearthed from this site, including inhumations, cremations and incompletely cremated burials (Figure 4).

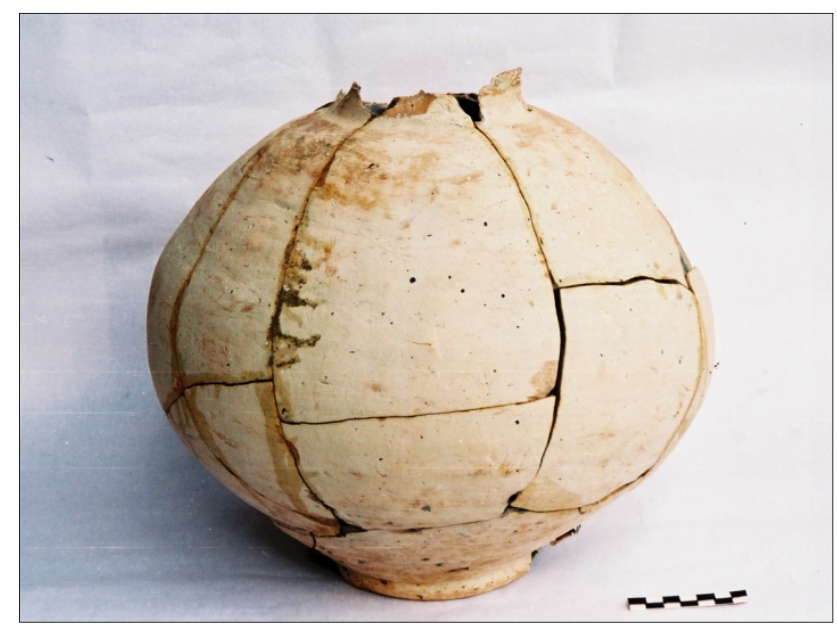

Figure 4: Cremated burial jar 01GT.M1, Minh Su Mount, Go Thap 
It is hard to say that all the burials followed the Hindu funeral ceremony, based on varieties of the graves and grave goods. However, several typical artefacts of pottery (simple clay linga, fragments of kudika and kendi) and pebbles (in the form of simple linga and beans) seem to indicate the rites related to 'Sivaist belief and probably the belief in fertility goddess (Le 2006b). Details of the grave goods will be discussed later.

\section{Settlement sites}

Unlike the temple sites in central and southern Vietnam, settlement assemblages are not very varied. They are mainly building materials, architectural decorations, sculptures and some types of ceramic, pottery and stone (vases, bowls, small lamps, kendi, kudika, grinding stones), which could be used for rituals. Archaeological evidence found so far from settlement sites is not clear enough to reconstruct Hindu daily ritual, as can be observed nowadays among Indian communities. On the other hand, the process of localization could make Hindu rites change greatly. In that sense, the small artefacts unearthed from settlement context are the subject of our focus. From several sites dated to the first half of the $1^{\text {st }}$ millennium AD, simple forms of linga have been unearthed, such as those from Go Cao Su, Nhon Thanh, naturalistic form of terracotta lingas found from Oc Eo, Giong Noi and the 'Sivalinga made of tortoise shell and potsherds found in Go Thap (Figures 5-7). In addition, trident images incised on tortoise shell and a large number of small pebbles found in the cultural layers in the Go Thap and Nhon Thanh sites suggests that Hindu ceremonies were popularly practiced (Le and Pham 2003; Le 2006a: H. 95-98; 2006b; Tran et. al.1999; Tran, Lai 2007).

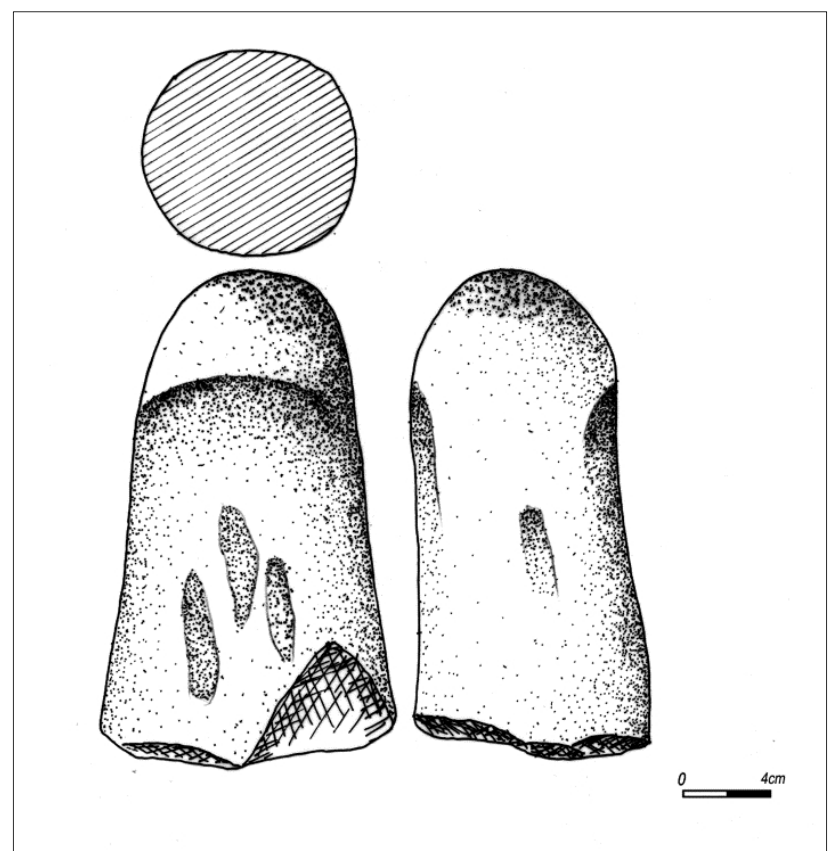

Figure 5: Stone linga in natural form, Nhon Thanh site (Drawing by Nguyen Dang Cuong).

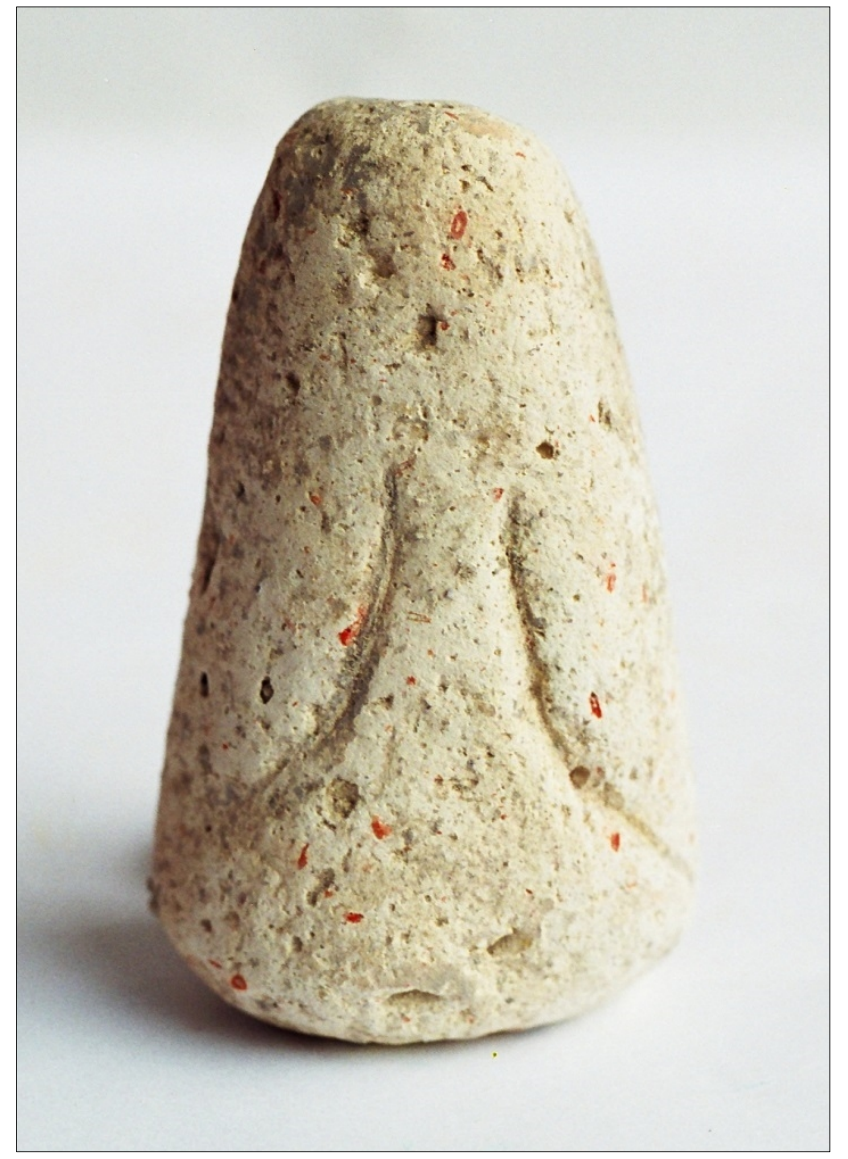

Figure 6: Terracotta linga in simple form, Oc Eo site.

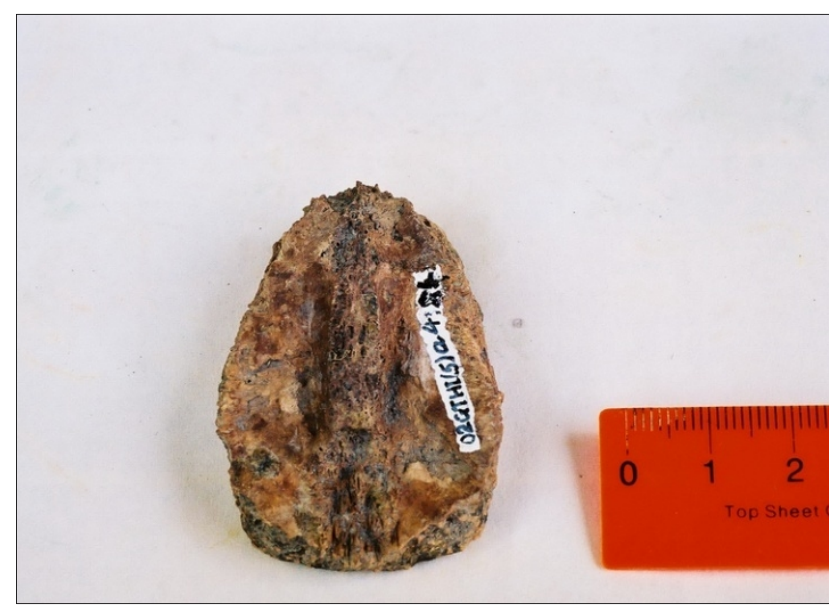

Figure 7: Tortoise shell linga in simple form, Go Thap site

\section{Workshop sites}

Evidence of workshops for the manufacture of Hindu sculptures and ornaments has been exposed at several sites, including Oc Eo, Nhon Thanh and Go Thap. In addition to a large number of imported golden artefacts found from Oc Eo, the stone molds with Hindu symbols and emblems from Oc Eo and other sites indicate that a large quantity of metal ornaments (mainly lead and tin alloy) bearing Hindu symbols were produced for the populace (Le 2011b). A number of finished and incomplete sculptures found from Go Thap site proves that it was a 
center for the production of both Hindu and Buddhist sculptures (Le, Nguyen 2010) (Figure 8).

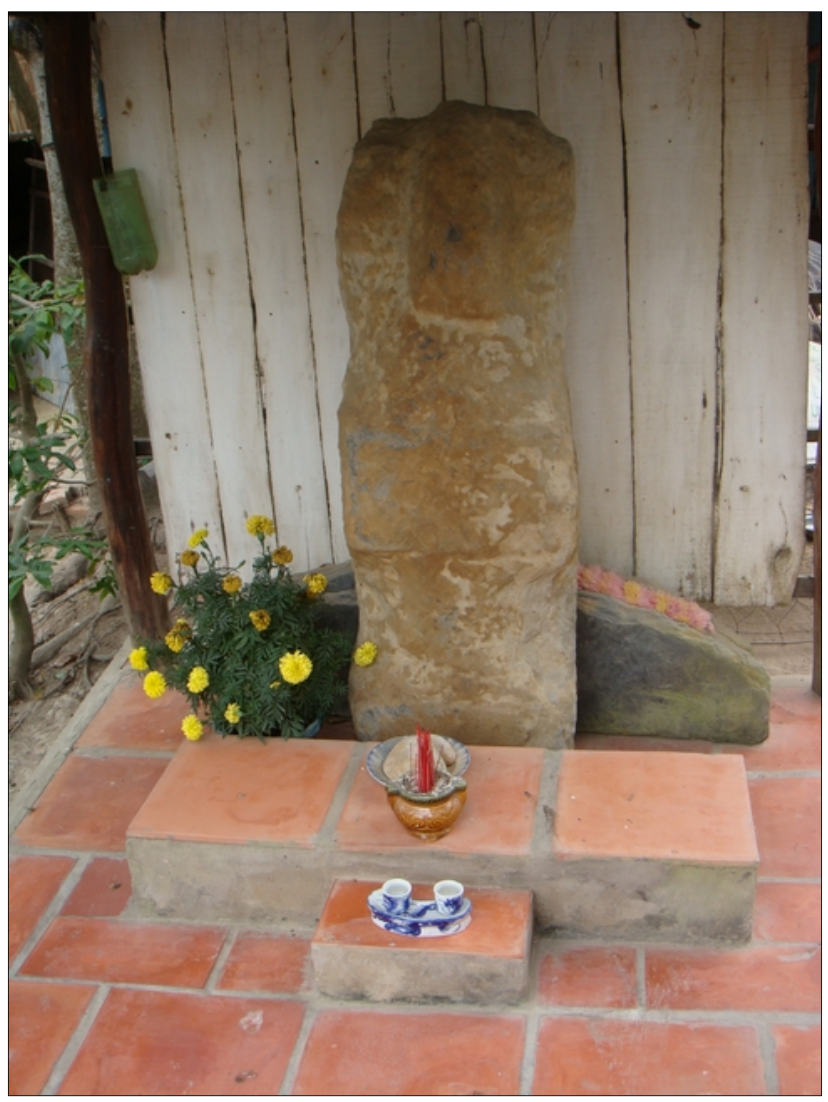

Figure 8: Unfinished sculpture, stone, Go Thap site.

\section{HINDU BELIEFS AS REVEALED BY THE ARTEFACTS}

Hindu beliefs were represented by several types of archaeological artefact. In addition to the most easily distinguishable images of gods and goddesses, tiny objects, such as miniature ornaments, pottery, temple offerings, grave goods and decorated motifs on all types of artefacts reflect various aspects of religious practices of the people.

\section{Sculptures and the representation of the supreme gods}

Sculptures are the most obvious evidence of Hindu belief and scales of patronage. Southern Vietnam shares several images from the common repertory of sculptures of mainland Southeast Asia (Thailand and Cambodia in particular) for Hindu gods and goddesses during the so called pre-Angkorian period (Guy 2014; Felten and Lerner 1988). However, the lack of uniformity and variable artistic quality of sculpture found from southern Vietnam during the $1^{\text {st }}$ millennium AD is noteworthy (Le 2014). Images of several gods are found from many sites that are, in some cases, closely related to temple remains. Linga and linga-yoni are found in largest number, following by number of Vișu images. Other identifiable Hindu gods and goddesses include Gane'sa, Sūrya, Brahmā, Harihara, Laksmī, and Mahisāsumardin̄̄ (Malleret 1959: 40910, Pl. LXXXVIIA; Le 2006a: 209, Table 2.7). An ac- count of art style and chronology will be presented to understand the role of these gods in society from time to time.

Images of Sūrya and Brahmā are rarely found and date mainly from the $5^{\text {th }}$ century to the end of the $7^{\text {th }}$ century. The Sürya image from Thap Muoi wears a type of sampot, which similar to that of Kompong Cham Sürya. While retaining some elements of north Indian prototype, this type of garment could have been modified greatly (Felten and Lerner 1988: 168-69, P1.3). The rounded and child-like features of the face make the Thap Muoi image more natural than and not as stiff as that of the Kompong Cham image. Details of the hair, mitre and halo suggest that he could be the predecessor or produced in the same period as the products of Phnom Da A style (Le 2006a: 102-103).

The role played by Viṣnuism in Southeast Asian trading networks has been discussed elsewhere, based on the discovery of large number of Vișu image, particularly in the early coastal states (Dalsheimer and Manguin 1998). Paul Lavy (2003: 21-22) otherwise argues that the popularity of Vispu and other Brahmanic deities was linked to patterns of political authority and that the Southeast Asian ruling elite, whether kings or chiefs, utilized images of the gods with these considerations in mind. He counts that 'Siva is only encountered on the right half of Harihara, who probably appeared for the first time in Southeast Asia during the $7^{\text {th }}$ century (ibid, 26-27). Evidence from southern Vietnam may add more information to these discussions. In addition to political and trading network contexts, the developmental trend of Hinduism in India intermingled with local traditions that contributed constant influences on religious practices and the appearance of gods and goddesses in local communities from the first half of the $1^{\text {st }}$ millennium AD. This argument is not only based on the large sized sculptures and temple architectures but also in the context of discoveries of other artefacts.

Among the 45 sculpture and bas-reliefs of Vișu images found so far from southern Vietnam, the earliest ones are from Nhon Thanh site (Can Tho province). They are very small in size, not higher than $30 \mathrm{~cm}$ in completed form. Iconographical features of the child-like face and details of the drapery indicate that they were imitated from several features of Mathura Gupta art of the $5^{\text {th }}$ century. One unfinished sculpture among this group shows that they were local products. Stylistically, the imitation of Indian original styles was preserved on some features and the creation of indigenous art forms can be realized more clearly (Le 2006a: 65-79, Ills 49-50; Guy 2014: Fig. 91). The common iconographical feature of Vișu in standing posture, with four hands holding the symbols of chakra, sankha, danda and a small ball - a representation of the Earth Goddess was the typical creation of Southeast Asian people, developed in southern Vietnam from the $5^{\text {th }}$ century (Figure 9).

Some Viṣnu images produced in the late $5^{\text {th }}$ to $6^{\text {th }}-7^{\text {th }}$ centuries are found further inland, from Go Mieu and PhuocLuu sites in Tay Ninh province. At Go Mieu site, 
the foundation of a small brick temple $(5 \times 5 \mathrm{~m})$ was also found. Vișnu images dated to the late $6^{\text {th }}-$ late $7^{\text {th }}$ centuries were also unearthed from temple architectural contexts, such as those from Go Thap, Go Thanh and Binh Thanh. They are larger in size in comparison to the earlier period, generally from about 1 to $1.48 \mathrm{~m}$. The Binh Hoa Viș̣u image unearthed from Dong Nai river in Bien Hoa city is even up to $1.6 \mathrm{~m}$ in height (Le 2006a: H.171). Thus images of Vișmu and other gods and goddesses might have been worshiped in their own temple in a religious complex of each geographical region during the mature phase of the Oc Eo culture $\left(5^{\text {th }}-7^{\text {th }}\right.$ centuries AD). Several iconographic features of Viṣnu can be also observed in the images of Gaṇe'sa and Mahișāsuramardinī, with two raised hands holding the chakra and the sankha. These features, along with the absence of images of other gods and goddesses from the late $7^{\text {th }}-8^{\text {th }}$ centuries indicate a tendency to combine the function and power of Vișu with other gods and goddesses, and to emphasize their power to protect the world.

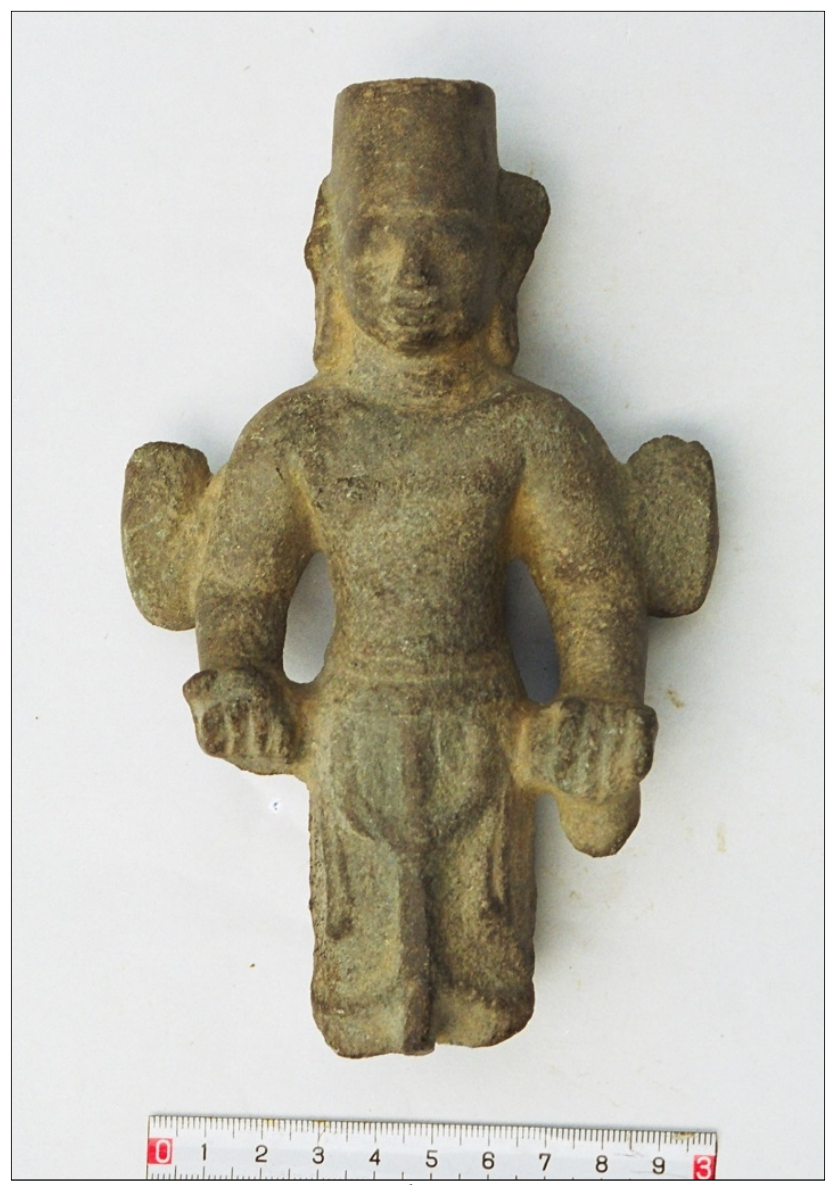

Figure 9: Viṣnu, stone, $5^{\text {th }}$ century, Nhon Thanh site.

The location and role of 'Siva temples in early Southeast Asia are still questioned. From the evidence of inscriptions and a number of unearthed Vișu images, there has been discussion on the earliest Indian influence related to the worship of Visnu and his various avatars (Dalsheimer \& Manguin 1998; Lavy 2003: 23; 2014). This is probably further supported by the small artefacts found from temple consecrated deposits in southern Vietnam, from Go Thap site particularly. However, one should not ignore the worship of 'Siva and his emblems. It is necessary to look closer to the development of iconography of 'Siva god in southern Vietnam.

In addition to one probably Ardhanārī'svara image, 'Siva in half man-half woman form, and one 'Siva image (Malleret 1959: 409-410; P1. LXXXVIIa), two heads of Harihara were found from Oc Eo- Ba The area. The first wears a mitre to represent Vișu and the third eye on the forehead to represent 'Siva. The child-like face and the feature of the mitre, which is reduced to the top, made him resemble the Vismu images dated to the $5^{\text {th }}$ century found from Nhon Thanh site. It could be the earliest of this type found from Southeast Asia so far (Figure 10). The second Harihara head was represented as a mature man, having a half jața-mukuta and a half of the third eye for 'Siva, and a half mitre for Viṣnu, which are close to those of the $7^{\text {th }}$ century Prasat Andet style (Malleret 1959: 409, P1. LXXXVIIb). It is clear that the worship of 'Siva in human form was not popular during the $1^{\text {st }}$ millennium $\mathrm{AD}$.

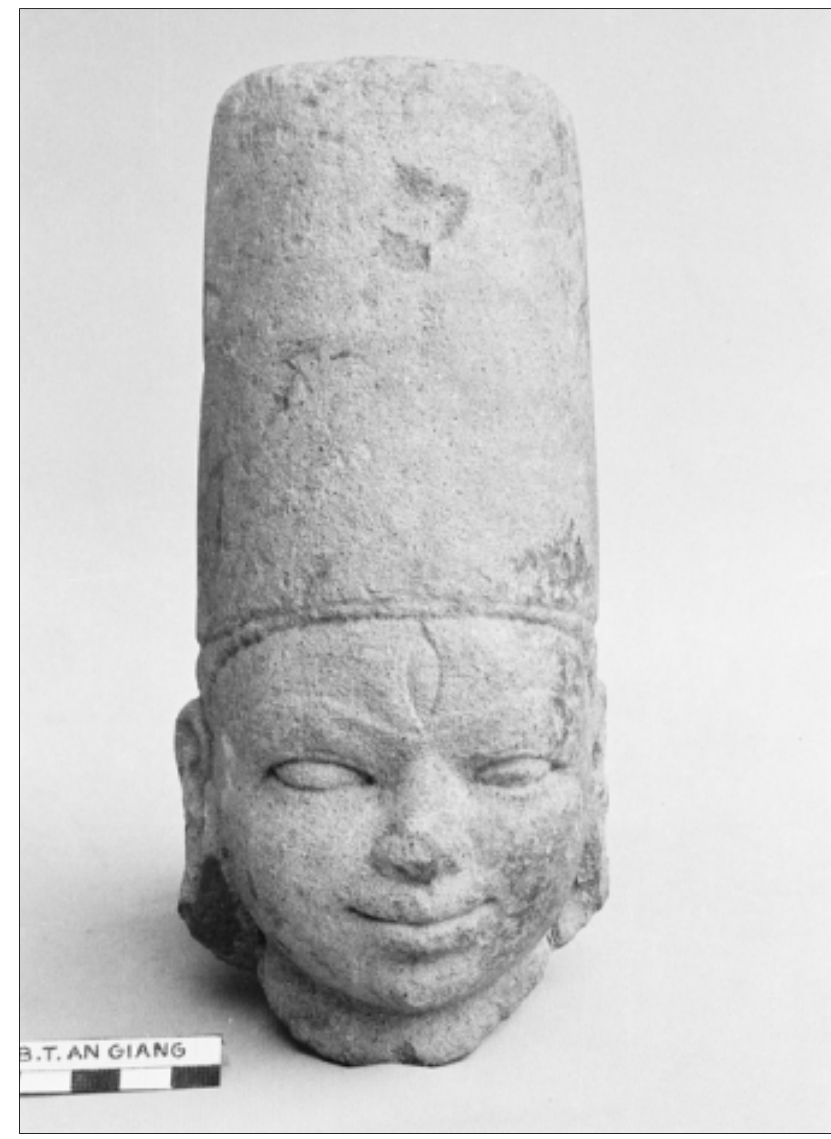

Figure 10: Head of Harihara, stone, $5^{\text {th }}$ century, sanctuary A4, Oc Eo site.

The 'Siva lingas are typical representation of 'Sivaism in southern Vietnam, and elsewhere in Southeast Asia. Although evidence of its earliest belief and practice is not very clear; or if the idea of a Svayambhuvalinga - the one that rose up and came into existence by itself - was 
acknowledged, Southeast Asian people in several places considered mountains to be holy and even respected as the symbol of the Supreme God, as the lingaparvata in Champasak and the Nui Chua (Mount Lord) in My Son (Quang Nam province). Standing out of the flat plain or in the coastal areas, several mountains could have been considered as sacred places in the Mekong lower delta, such as Mount Bay Nui, Mount Sam (Chau Doc) and Mount $\mathrm{Ba}$ The. On the slope or surrounding the foot of these mountains, vestiges of temples and artefacts are often unearthed. Mount Ba The, in the complex of the Ba TheOc Eo site (An Giang province) probably served as the sacred mountain of the Oc Eo people (Manguin 2002: Table 3).

Before the $5^{\text {th }}$ century AD, both 'Sivaism and Visnuism were followed by the Oc Eo people, as observed from the presence of Hindu symbols, incarnations, and vehicles of the gods (Malleret 1960: Pls. XCVI, XCVIII, CI, CIX-XI; Le 2005). The presence of a huge stone linga in phallic form found at Go Cay Trom (Oc Eo) and a large architectural foundation $(30 \times 15 \mathrm{~m})$ unearthed on this mound suggests that an important Siva temple existed in Oc Eo city during the first half of the $1^{\text {st }}$ millennium AD. Several other 'Sivalingas with realistic features have been found from the mountains of Ba The, Bay Nui, Nui Sam and one from Vat Chrăk (Rach Gia, Kien Giang province). They indicate that Go Cay Trom was not the only 'Siva temple during this early period (Le 2006a: Table 2.3, No. 1-9).

In connection with the appearance of Vișu and other Hindu images, the iconography of 'Siva Mukhalingas should be taken into account. Among 11 sculptures of 'Siva Mukhalinga found from southern Vietnam, seven sculptures are dated from the $4^{\text {th }}-5^{\text {th }}$ to the $6^{\text {th }}-7^{\text {th }}$ centuries, three of which are from Oc Eo-Ba The. The most noticeable one was found from Oc Eo. 'Siva was represented with fleshy rounded face, large and hollowed eyes, realistic features of ears, nose, lips and chin. The god was carved on a tripartite type of achalalinga which is datable to the $5^{\text {th }}$ century. The height $(0.92 \mathrm{~m})$ of this sculpture indicates that it was the main idol object in a sizable temple (Figure 11). Two others sculptures found from Oc Eo and $\mathrm{Ba}$ The mound are datable to later dates according to their iconographical features (Le 2006a: 86-88, 229).

Other types of Sivalingas found indicate various levels and ways of practices of the 'Sivaist followers. A stele in form of a simple- linga, which was carved with a trident in the plenty vase, from Canh Den site indicates the present of the Lakulisa's followers in the area during the $4^{\text {th }}-6^{\text {th }}$ century AD (Le 2006a: Fig. 92; Guy 2014: 161). A small realistic gold linga attached on a bronze recessed pitha was buried among the consecrated deposit in temple foundation No. M2 at Da Noi site. A large size linga-yoni of the same type $(0.575 \mathrm{~m}$ in total height $)$ was unearthed from Ba The (Le et. al 1995: 365; Le 2006a: H. 133-134) (Figure 12). They still preserved the natural form of the rudrabhāga and are datable to the $5^{\text {th }}-7^{\text {th }}$ centuries.

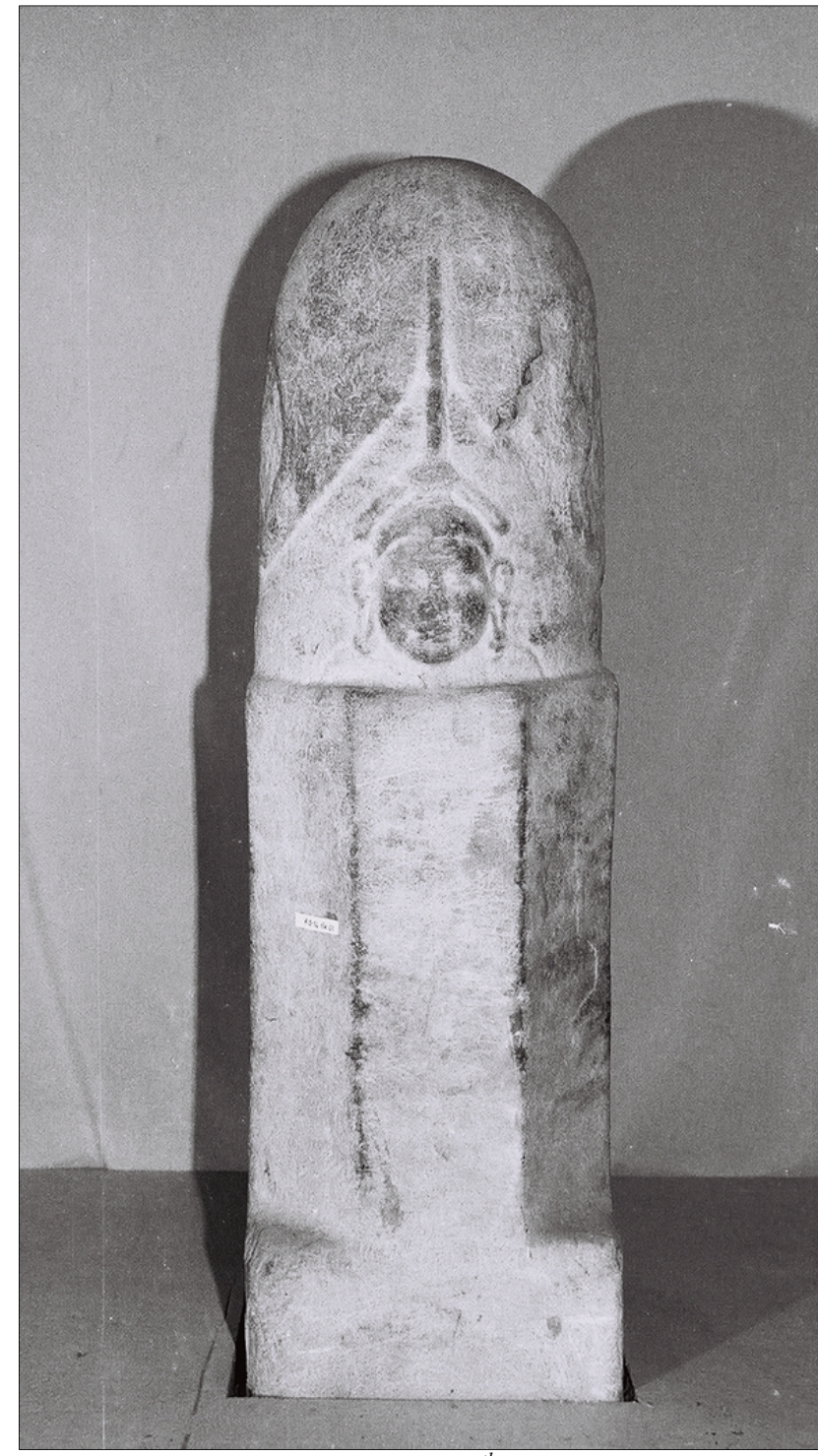

Figure 11: Mukhalinga, stone, $5^{\text {th }}$ century, Oc Eo site.

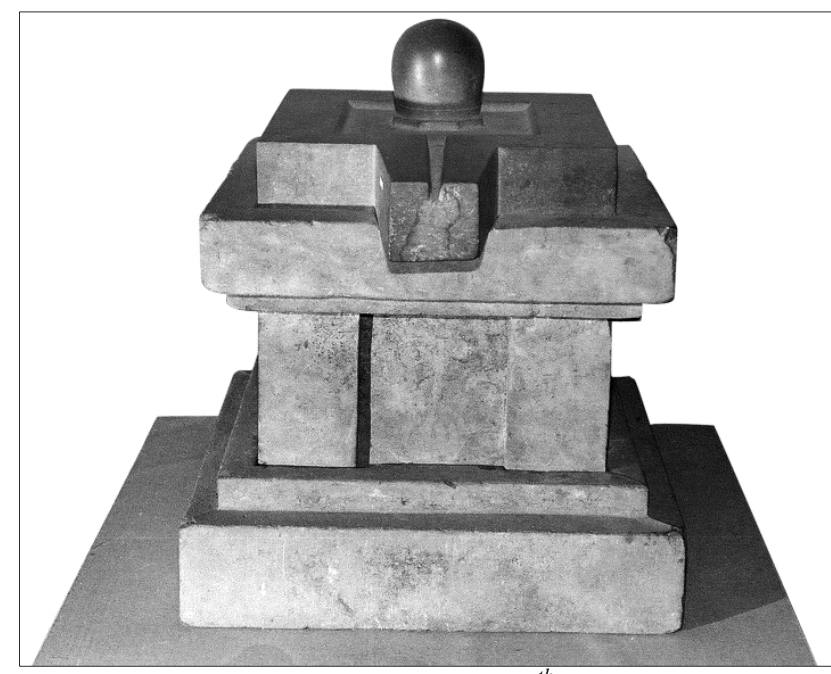

Figure 12: Linga-yoni on pitha, stone, $7^{\text {th }}$ century, Oc Eo site. 
The evolution of the linga in India, which culminated in the conventional medieval type, contributed greatly to the evolution of the linga in southern Vietnam, in particular the tripartite structure type. There are eight notable lingas of this group. Stylistically, they are datable to the period late $5^{\text {th }}-7^{\text {th }}$ centuries. The largest one is found from Cay He pagoda (Tra Vinh province), which suggests a large temple existed for the worship of Siva in this area. The Rudrabhäga of the linga found from Go Thap site was realistically sculptured. The height of this sculpture $(1.46 \mathrm{~m})$ also suggests an important temple was built for 'Siva god (Le 2006a: Ills. 114-115). Thus the appearance of sizable sculptures of both 'Sivalinga and Vișnu in the major Oc Eo sites during this period suggests elite support for the construction of their temples.

In later periods (late $7^{\text {th }}-8^{\text {th }}$ centuries $A D$ ), temples for the worship of more advanced and sizable types of 'Sivalinga, Cat Tien site for example, were still constructed in the highland areas. However, many sites in the lower delta of the Mekong River lost their role.

Temple consecrated deposits - Gold plaques as means of representation of the Hindu pantheon

Hindu beliefs were practiced in several ways and can be recognized mainly by the presence of typical symbols in clear archaeological contexts. In the first half of the $1^{\text {st }}$ millennium $\mathrm{AD}$, it is hard to find sizable sculpture of Hindu images. However, rich sources of Hindu symbols and, in several cases, images of god and goddesses have been found in the consecrated deposits from temple architectural remains. They suggest the worship of many gods and goddesses in a crowded pantheon of Hinduism.

The simplest forms of Vishnu's incarnations and symbols, such as kurma, matsya, varaha, garuda, 'saṇkha, cakra are identified on gold plaques from the consecrated deposits of the brick structures in the Grave Mound area at the Go Thap site. Symbols of 'Siva and other gods and goddesses from this site were also represented in the same way (Figures 13, 16). Belief in a mother goddess was prominent, as indicated by the symbols of the lotus and the water vase, which were generally combined with symbols of 'Siva or Vișu (Figures 17-18). This site is assigned to the early period of Hindu art in the area (before the $5^{\text {th }}$ century $\mathrm{AD}$ ), based on archeological context and inscriptions (Figures 19-20). More advanced and complicated representations of Hindu emblems are observed from other sites, such as Da Noi and Cat Tien, which are datable to the $4^{\text {th }}-6^{\text {th }}$ centuries and late $7^{\text {th }}$ - late $8^{\text {th }}$ centuries respectively. It is noteworthy that the content of inscriptions and images from the Cat Tien temples represent a fully developed type of a Mandala of the Hindu world, with the presence of the Dikpalas - the gods of directions, the gods of the cosmos and many other Hindu gods and goddesses. The archaeological context of the site also suggests that Hindu ceremonies accompanying the construction of an important temple were followed, but could have been modified greatly (Ślączka 2007: 224226, Le, Witzel 2008).

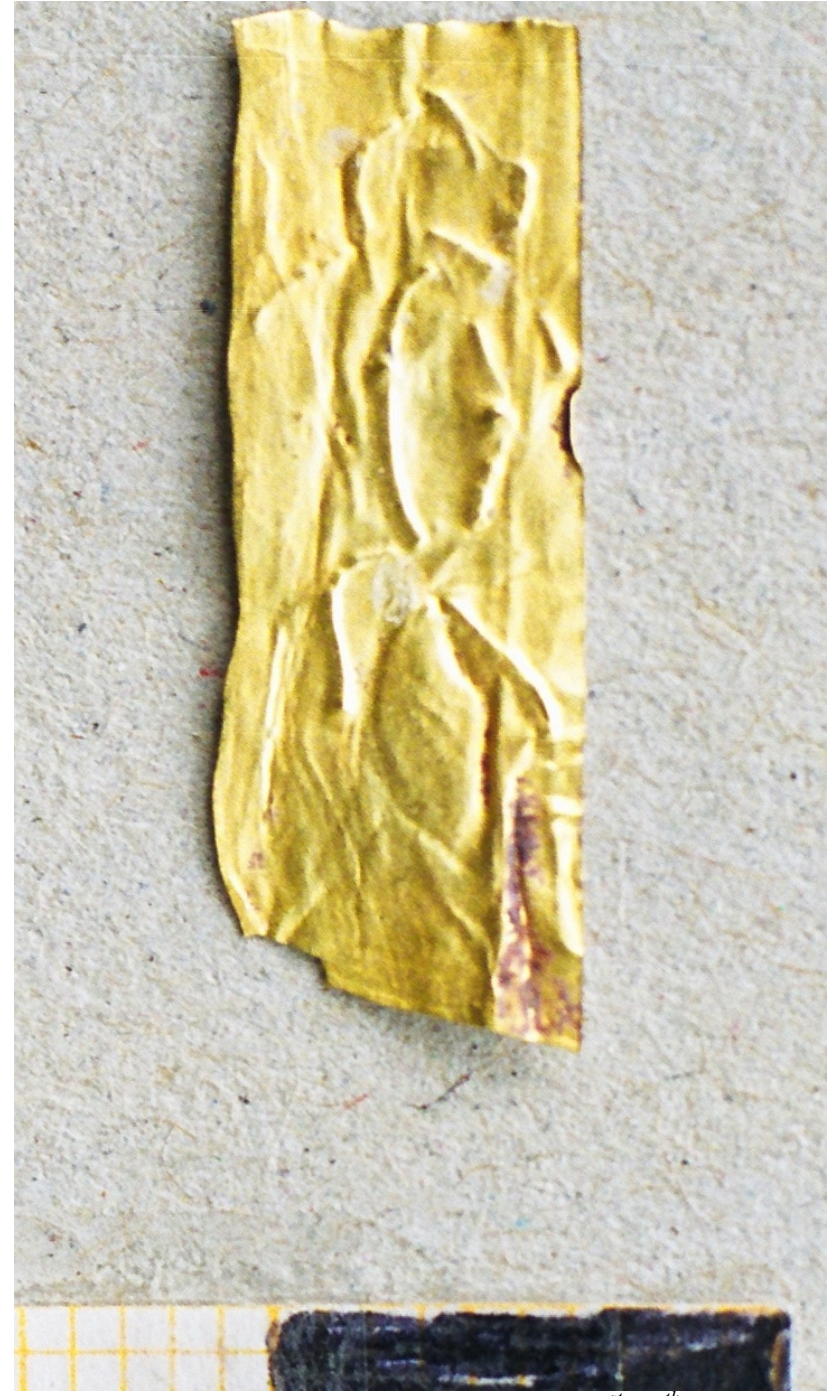

Figure 13: Gold plaque with Varaha image, $1^{\text {st }}-4^{\text {th }}$ centuries, Go Thap site.

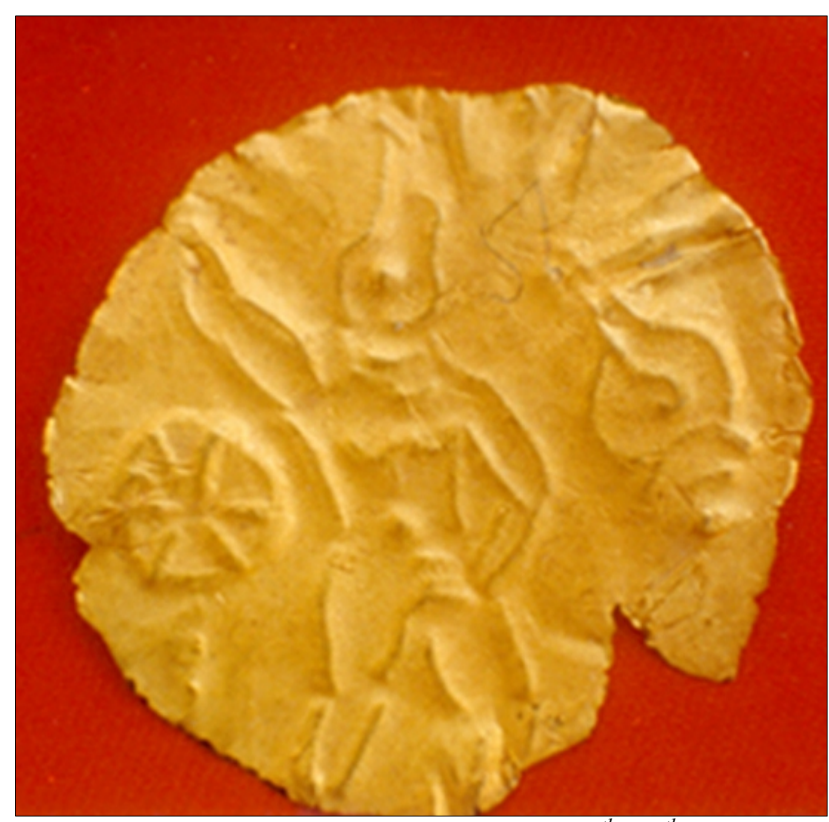

Figure 14: Gold plaque with Varaha image, $4^{\text {th }}-6^{\text {th }}$ centuries, Da Noi site. 


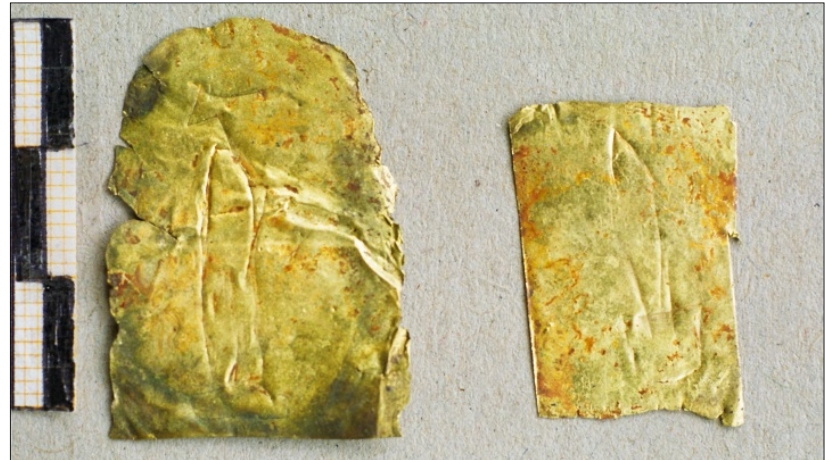

Figure 15: Gold plaques with linga image, $1^{\text {st }}-4^{\text {th }}$ centuries, Go Thap site.

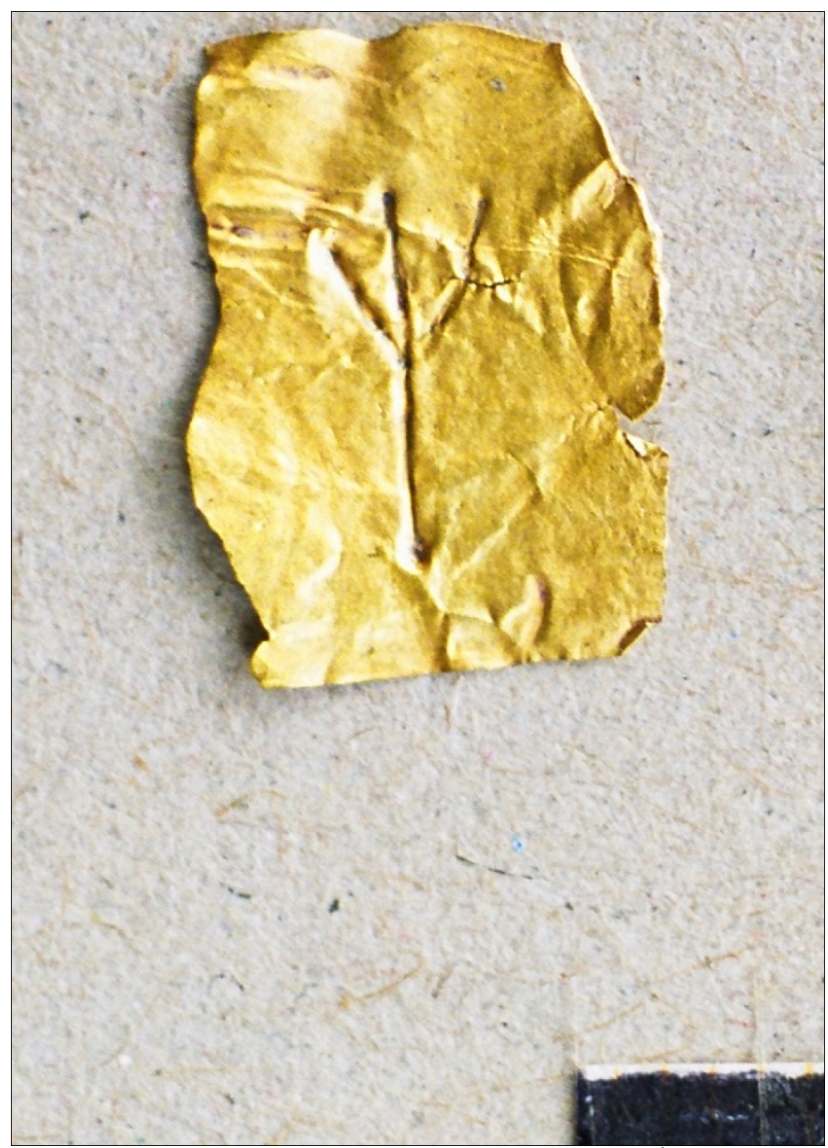

Figure 16: Gold plaque with Vajara image, $1^{\text {st }}-4^{\text {th }}$ centuries, Go Thap site.

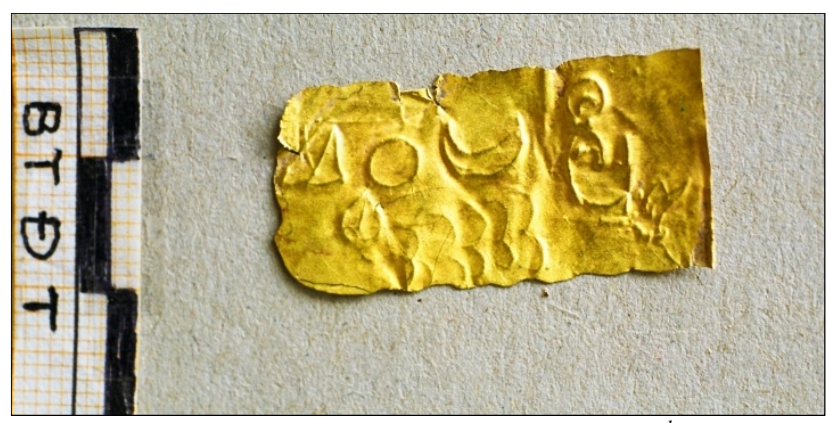

Figure 17: Gold plaque with Hindu symbols, $1^{\text {st }}-4^{\text {th }}$ centuries, Go Thap site.

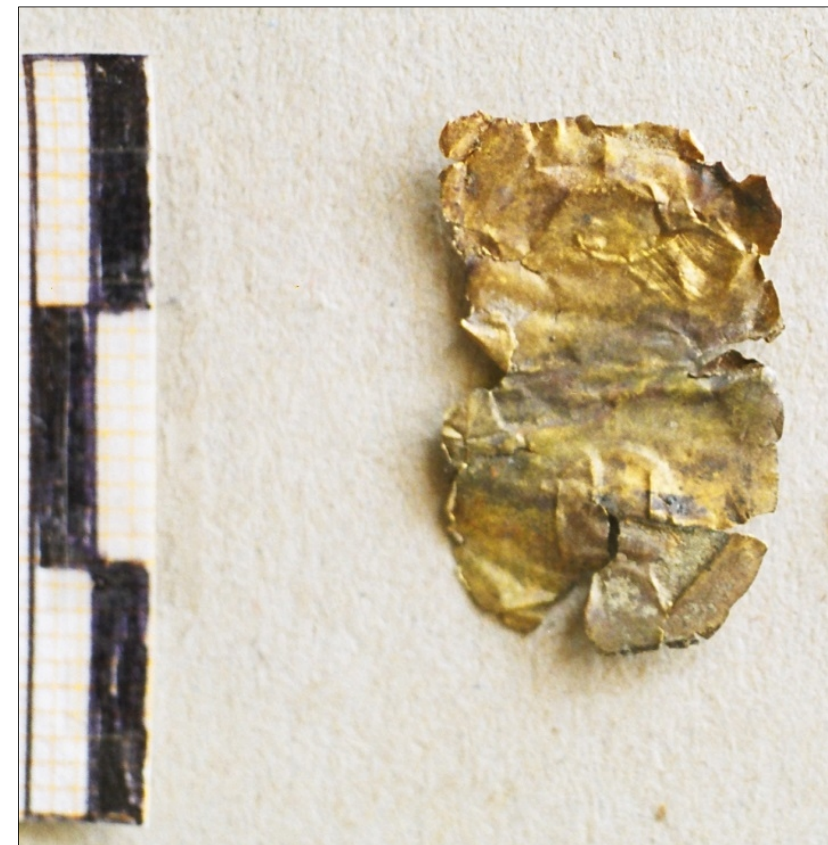

Figure 18: Gold plaque with vase image and letter "ma", $1^{\text {st }}$ $4^{\text {th }}$ centuries, Go Thap site.

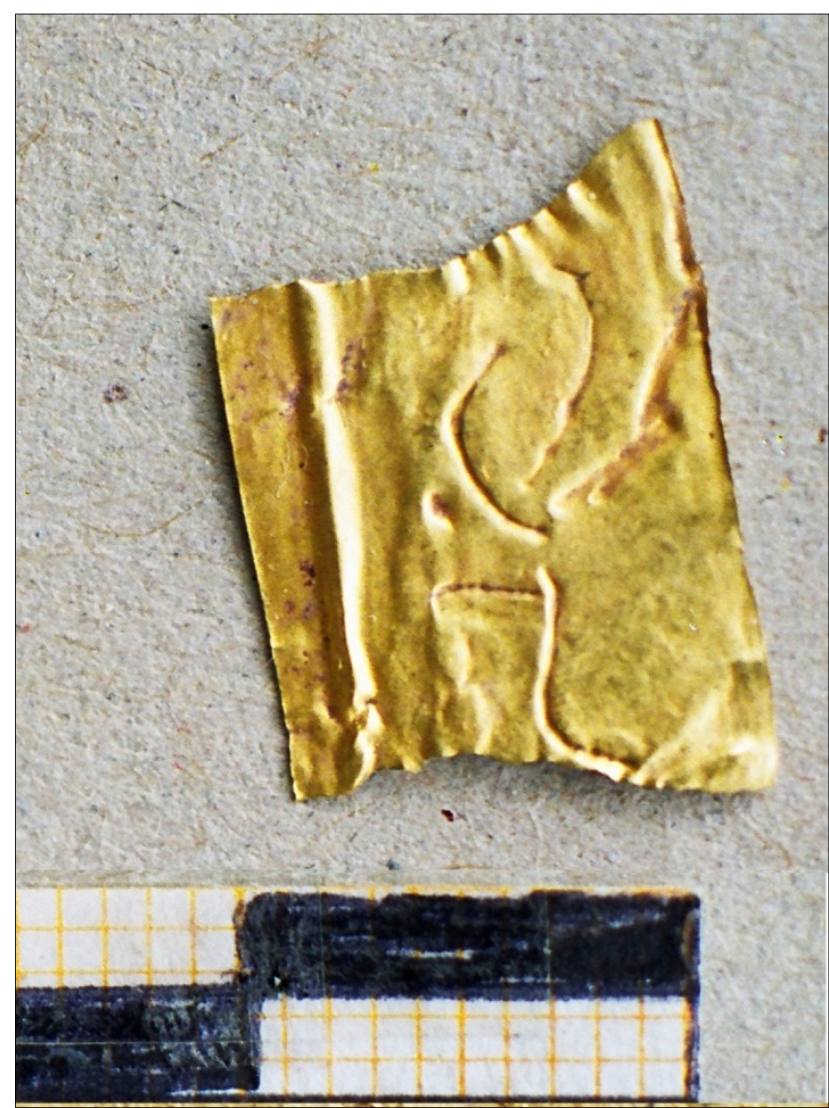

Figures 19: Gold plaque with inscription, $1^{\text {st }}-4^{\text {th }}$ centuries, Go Thap site. 


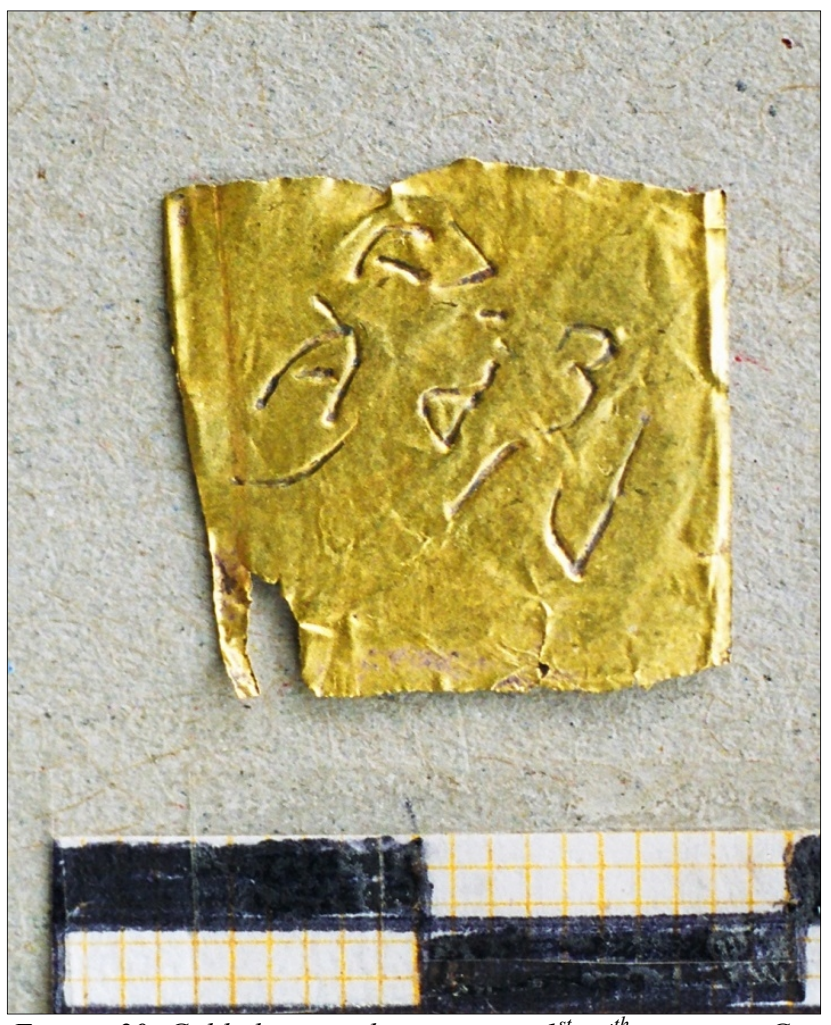

Figures 20: Gold plaque with inscription, $1^{\text {st }}-4^{\text {th }}$ centuries, Go Thap site.

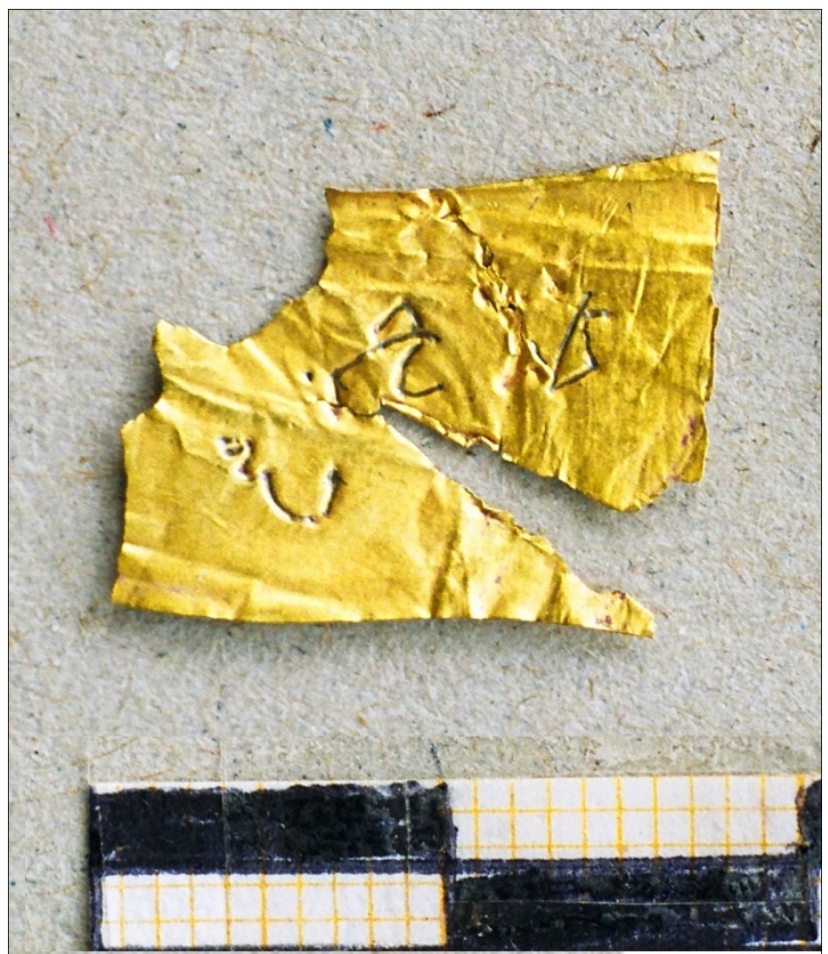

Figures 21: Gold plaque with inscription, $1^{\text {st }}-4^{\text {th }}$ centuries, Go Thap site.

\section{Grave goods and burial ceremonies}

Although there are several sites that are defined as cemeteries, the burial customs of Oc Eo's populace are still unclear. The status of the grave owner of the Linh Son 1 grave is not clear from the grave goods.

From Go Thap site, three types of burials are recognized:

1. The first type represented inhumation burial; the dead were placed in a rectangular pit dug into the virgin soil. Only one burial (02.GT.H1.M4) of this type was found and is incomplete and probably disturbed by other burials. Excepting one marker stone and some pottery fragments, no special grave goods were found.

2 . The second type burials represented several ways of burying the cremated ashes of the dead person. Most of the graves were disturbed by each other. In grave 01GT.H1M1, the ashes were contained in a jar and buried in the funnel-like pits, together with the grave goods and covered by potsherds and fragments of bricks; in grave 02.GT.H1.M6 the ashes were put on a square brick and covered by the bottom part of two jars which were inserted to each other. In some cases, the potsherds were scattered in the bottom of the grave with one or two stones in the middle. Sand and clay was used for coating the wall or the bottom of the burial pits. Tortoise shells were always present in these burials (Pham and Le, 2001; Le and Pham 2003).

3. In the third type the skull was buried with the cremated ashes. In one case, the skull and ashes were arranged in a figure of eight that was bordered by grayish clay in a rectangular grave pit.

Rather rich assemblages of grave goods have been unearthed from types 2 and 3 . In ten of 25 identified cremated burials, stone artefacts are found. They are mainly fragments of grindstone, pestle and natural stones. In two cases, the arrangement of the stones is noteworthy. In the bottom of burial 02GT. M16, potsherds were scattered in a circle. A stone was laid in the middle. Another whitish stone was laid on the northern border (Figure 23). In the second case, a large rock was laid in the middle of a possible large grave pit (Le et. al. 2005). Breaking the pottery before scattering them in the grave pit became a fashion. Among varieties of pottery, fragments of kendi found in almost all burials and fragments of kundika found in several cases. In two burials, half a lead earring was found. The custom of laying tortoise shells under the burial jar is observed in almost all cases. 170 small pebbles were unearthed from the excavations, many of them from burial context. The pebbles were well selected for color and form, including bean-shaped, egg-shaped, oblong with one end pointed, ellipse, half-moon etc. Some were incised on the surface. A pebble incised with image of a simple vajra and one another with a Brahmi letter " $m a$ " were unearthed from a burial context during the 2003 excavation (Le et. al 2005). The possible use of these pebbles in a Hindu ceremony for the deceased is further indicated by the discovery of the similar small terracotta object in triangle cubic form (Figure 22). It is difficult to fully interpret the burial customs of the people in Go Thap site. However, data strongly indicates that Hindu funeral rites were practiced during the first half of the $1^{\text {st }}$ millennium $\mathrm{AD}$. 


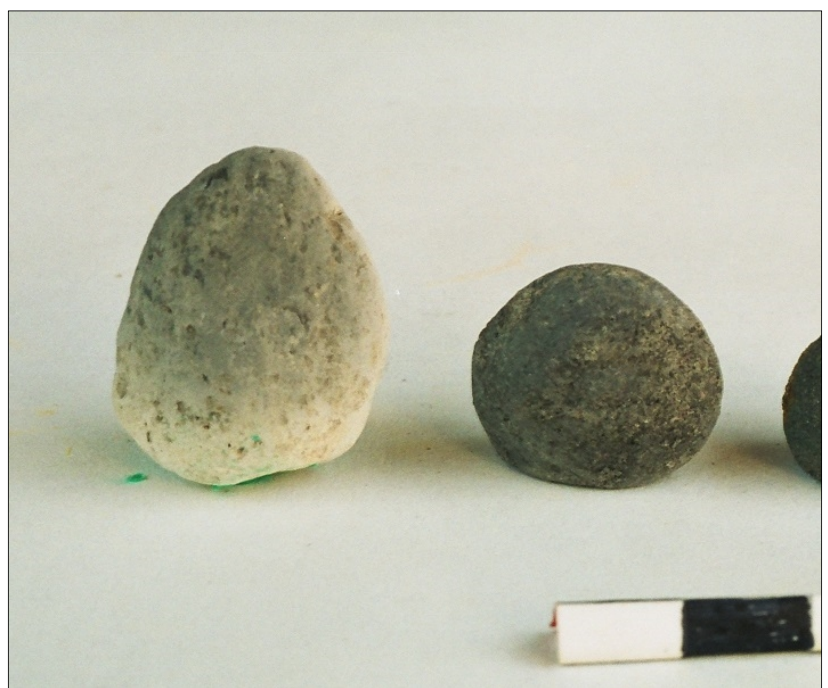

Figure 22: Terracotta artefact as grave goods, Go Thap site.

\section{Hindu belief practices among the populace}

Archaeological data provides information on various types of artefacts used in daily life, which may to some extent reflect popular beliefs in Hinduism. Ornaments are the most common finds. An analysis of small artefacts, consisting of ornaments and molds, coins, intaglios, ceremonial objects, seals and beads shows that there are at least 22 types of symbols and images of gods and goddesses; many of them represent Hindu emblems (Le 2006a: Table 2.4). Collections of molds from Oc Eo and Nhon Thanh sites indicate that a large number of ornaments could be produced to serve local demand. Amulets, earrings, bangles (mainly made of tin and lead) bearing the images of conch, makara, 'Siva trident in a vase, lotuses in the vase, fish, the wheel, Varaha were prevalent. On the other hand, Nandi bull was preferred for gold rings (carving on gems or molding) and crystal seals (Malleret 1962: P1.XV, No, 3067; Pl.XXVII; Le 2006a: Ills. 211212).

Tiny lingas (chalalingas) are found in various contexts. In several temple consecrated deposits, small lingas made of gold, silver, bronze and stone, rock crystal in particular, are included. Three gold lingas of similar size and tripartite type are found from the consecrated deposit of Temple 1A at Cat Tien, among several images of the same gods and goddesses and inscriptions. This could have been an indication of people belonging to various statuses, including most probably royal family members who participated in the ceremonies of temple construction. The question of who offered the gold plaques to the consecrated temple depositions is also concerned. Some gold plaques were incised with inscriptions. Various Brahmi letters noted the name of the Varaha, Nāga, Varuna, vajra, padma, triśúla and 'Seșa are recognized on the gold plaques from Go Thap and Da Noi sites or the name of the Dikpalas from the Cat Tien site. Some inscriptions seem to represent the prayers of the people. In some cases, the pronunciations reflect a dialect other than Sanskrit (personal communication with Prof. Michael Witzel in 2007). The letter " $m a$ " was incised on several pieces with the image of a vase or a goddess (Witzel and Le 2001: 775-777: Le 2006a: 137; Le, Witzel 2008, Le 2013) (Figure 17).

Small lingas made of stone are found from both temple and settlement contexts. Going back several centuries to the early Christian era, some groups of people probably practiced the worship of Siva, even when the colossal temples were not yet built. This hypothesis is attested by the present of a small stone linga found from $\mathrm{Go} \mathrm{Cao} \mathrm{Su}$ site (Long An province) having the rounded top and nearly square base with scars on the surface (Tran et. al. 1999). The tapered pebble with a rounded end and vertical grooves on the body found from Nhon Thanh site could have also been worshiped as a natural 'Sailajalinga (Figure 5).

The terracotta linga unearthed from Oc Eo are noteworthy (Figure 6). Rao (1916: 78) reported that a linga made of clay gathered from the river banks grants landed estates, whereas those of uncooked and cooked rice grant the worshiper plenty of food; one made of jaggery confers all desired ends. It is hard to identify the organic remains of these linga. In Oc Eo society, in which irrigated rice played important role, these types of linga were most probably used in Hindu rites. The 16 pottery "lingas" from Giong Noi site represents a phallic appearance. The inside is hollowed and a hole of about $1 \mathrm{~cm}$ was pierced in the top part. The lower bent base might be served as the basin or yoni. Among large numbers of unearthed artefacts, terracotta and stone tortoises, stones in half round, conical and rectangular cubic shapes were also found from this site (Tran and Lai 2007: 28-30, Ills. 22-25; Lai, Phan 2007: 42: Ills. 6, 7). Pieces of tortoise shell incised with tridents or cut into the 'Sivalinga form unearthed from the settlement area at Go Thap site can also be interpreted as evidence of popular Hindu practices (Le 2005b: 848) (Figure 7). Similar artefacts are found from Oc Eo site (Malleret 1962: P1. LXXXV-LXXXVIII). Tortoise images made of precious stone, cut from or incised on gold plaques were found from several temple consecrated deposits, both Hindu and Buddhist. It was believed to be for the stability of the temple. The same meaning might have been applied for the rituals in individual houses, in relation with the ritual of 'Siva cult.

In addition to the custom of scattering pebbles in the burials mentioned above, small pebbles unearthed from the settlement context at Go Thap and Nhon Thanh sites suggest their function in the specific ceremony. Their form and sign, suggests the rites that linked the worship of Hindu gods, 'Siva in particular, with that of the goddess of Fertility or Mother Goddess.

Chipped potsherds are found from many prehistoric and historical archaeological sites. Coarse or fine ware pottery was generally chipped into a roughly round shape. Their function is unclear. At Go Thap site, 92 chipped potsherds are found from the excavations at the Minh $\mathrm{Su}$ mound site, in both burial and settlement contexts (Le, Pham 2003; Le et. al. 2005). The form and degree of finishing of several pieces are noteworthy. Most of them were carefully chipped and polished to represent the 
round, ovoid, triangle, polygonal shapes. A hole in the middle of one round piece makes it resemble a coin. Some pieces were cut into halves, thirds or fourths (Figure 25). Some pieces in half-ovoid shape represent similar features to those of tortoise-shell linga found from the same site and thus suggest their function in Hindu ceremonies.

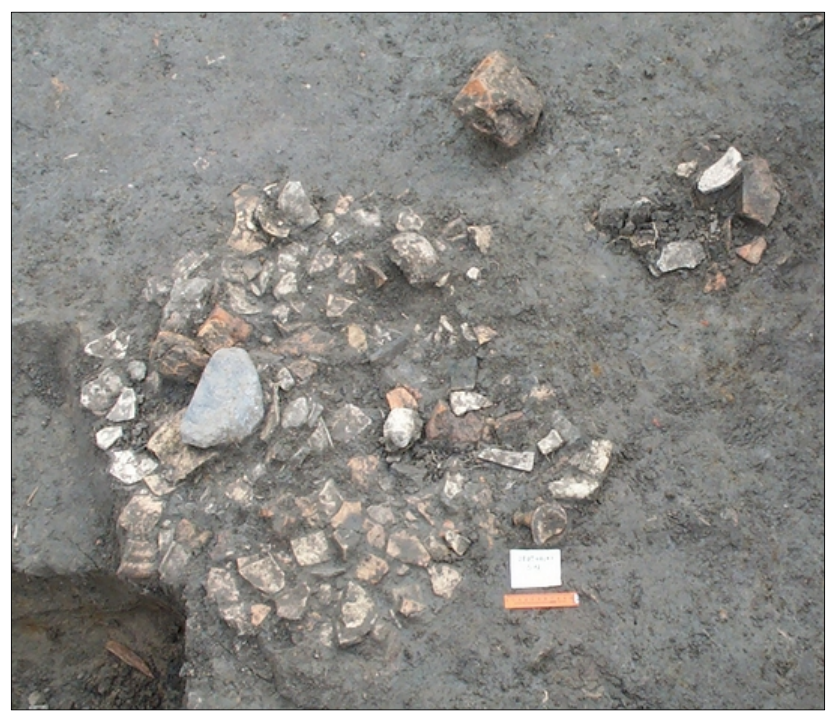

Figure 23: Burial remains scattered with fragment of pottery and stone, Go Thap site.

\section{CULTURAL EXCHANGES - NATURE AND THE ROLE OF MARITIME NETWORKS}

The $1^{\text {st }}$ millennium BC and early centuries of the Christian Era witnessed the blooming of cultural interaction and trading, which resulted in the development of social complexity in some Southeast Asian communities. The development and transfer of Metal Age technologies, metallurgy in particular, provide various agricultural groups in Southeast Asia with prosperity and created the strong base for some groups to play leading roles in trading networks in later periods. Regional and inter-regional contacts among Southeast Asian peoples resulted in the sharing of several cultural elements. Dong Son drums were favorites for the power, privilege and prosperity of local chiefdoms, particularly during the $1^{\text {st }}$ century $\mathrm{BC}$ $1^{\text {st }}$ century AD (Imamura 2006: Fig. 6; Bui 2008: Figs. 10-12; Nishimura 2008; Reinecke et. al. 2009: 79-84); nephrite and glass earrings of Southeast Asian styles are distributed and manufactured in pan-Asian sites as indication of early trading centers (Hung \& Bellwood 2010).

At larger scales, demands for luxury goods, spices and forest products from South and Southeast Asia by the Chinese, Middle East and the Mediterranean world during the first six centuries AD have been strong motives for expanding trading networks, in which Indian and Southeast Asian merchants and craftsmen played important roles (Rajan 2011: 177-196). Chinese, Central Asian and the Mediterranean material culture are unearthed not only from the early port sites of Khao Sam Kaeo, Oc Eo, Arikamedu, Hepu etc., but also from further inland sites. Han
Chinese bronze mirrors, bronze bowls, seals and pottery are unearthed from Binh Yen, Go Dua, Go Cam, Tien Lanh sites in central Vietnam (Nguyen et. al. 2006: Fig.21.7; Yamagata 2006). Whereas Mediterranean glass eye beads from Go Thap site, terracotta figurines and musical instruments from Nhon Thanh site and two terracotta figurines in Chinese style also from Go Thap indicate a closer contact via the river systems with local people and most probably the presence of a proportion of foreign population in Southeast Asia and southern Vietnam during the first centuries BC and AD (Le 2006b: Fig. 22.10; Nguyen \& Nguyen 1995: 75, Fig. 1, 77: fig. 5).

From the written sources, it is clear that political situation and policy of economic and religious expansion of the Chinese, Roman and Indian rulers could make great impacts on the propagation of religions in Southeast Asia (Borrel et. al. 2014: 110-112; Ray 2014).The rise of the mercantile community in India during c. 200BC $300 \mathrm{AD}$, including the development of the trading and craft guilds was another important factor in the expanding of maritime trade (Thapar 1992: 109-115). While the Chinese and Romans seemed to focus strongly to the development of diplomatic trading with each other, the Indian, following the idea of King Asoka, created "peaceful" cultural interchanges with other counterparts. Thus, as Himanshu Ray suggested, oral transmission of religious ideas and practices by priests and pilgrims, traders, wandering story tellers and entertainers should be taken into account to have a holistic understanding of cultural interaction across the maritime world (Ray 2014: 149). In this perspective, the strong impact of Indian religious practices among coastal groups in early history and their role in royal courts of rising Southeast Asian powers can be recognized from archaeological data. New research on technology, glass and stone beads making in particular, also led to common agreement that cultural exchanges were not one way, and did not simply imply Indianization or Sinicization, but reflect Southeast Asianization and localization (Bellina 2003; Hirano 2008; Bellina and Glover 2004: 68). Ban Don Ta Phet, Phu Khao Thong and Khao Sam Kaeo in Thailand, Sa Huynh sites in central and several Iron Age sites in the coast of southern Vietnam are among the most important sites for understanding the nature and the role of maritime networks in Southeast Asian state formation processes (Glover, Bellina 2011; Lam 2011; Bui et. al. 2012: 57-110, Bellina 2014).

Interesting ways of idea changes and religious propagation are recognized by the presence of foreign and local artefacts found from several sites. The carnelian and rock crystal beads in forms of lions, triratna and gada, seal with image of conch shell, pottery with triratna sign, discovered from burial and settlement contexts at Ban Don Ta Phet, Phu Khao Thong, Khao Sam Kaeo (Thailand), Lai Nghi, Go Cam, Hoa Diem (Vietnam) indicate that Buddhist and Hindu ideas were widely familiar (Lam 2011: Fig. 1.2; Glover, Bellina 2011: Fig. 2.15; Nguyen et. al. 2005: Fig. 21.15) (Figure 24). At the same time, beliefs about fertility and reproduction were realistically represented in the Metal Age, such as terracotta phalluses 
and pots with nipples from Long Thanh (Quang Ngai) and Hoa Diem (Khanh Hoa) (Figures 25-27).More developed types of rock crystal lingas from Vinh Yen site (Khanh Hoa) and pottery lingas from Giong Noi site indicate the possible combination of local and new coming ideas in ritual practices among these coastal people during the last centuries of the $1^{\text {st }}$ millennium BC and the early Christian Era (Tran et. al. 2012: Bv. 27, Ba. 14).

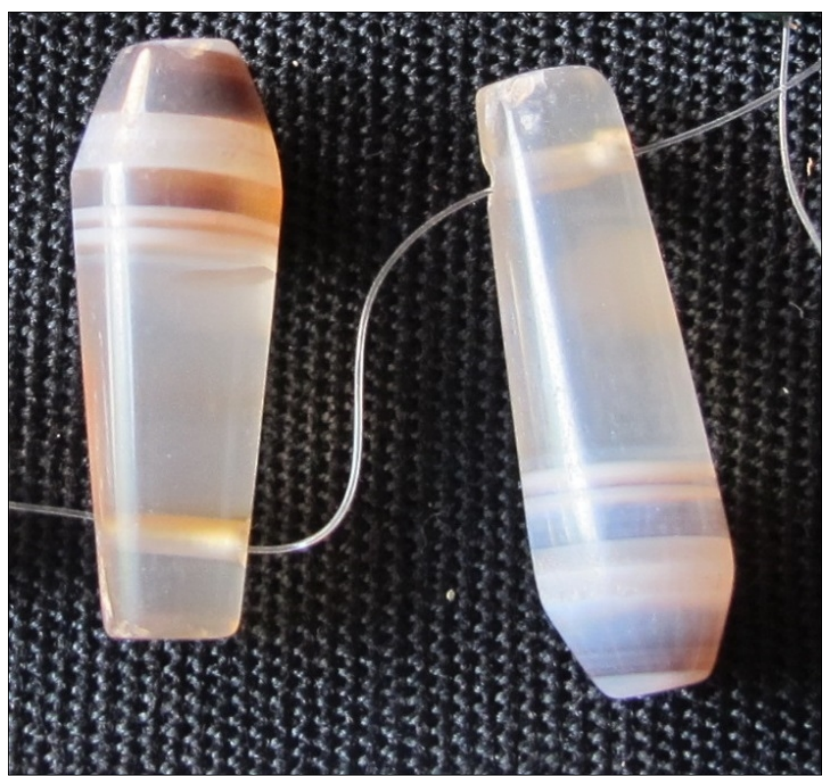

Figure 24: Beads in form of gada, Hoa Diem site.

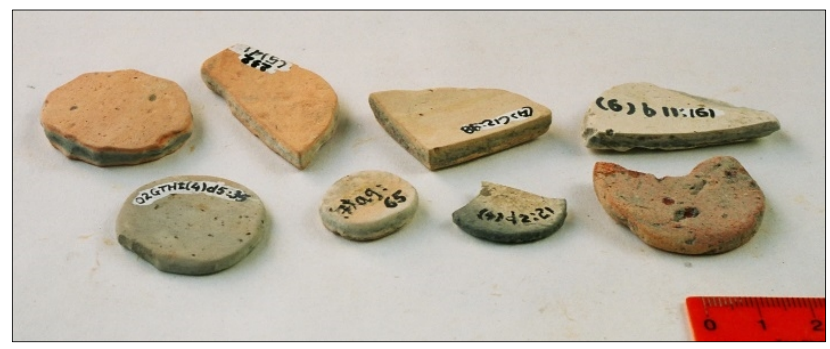

Figure 25: Chipped potsherds, Go Thap site.

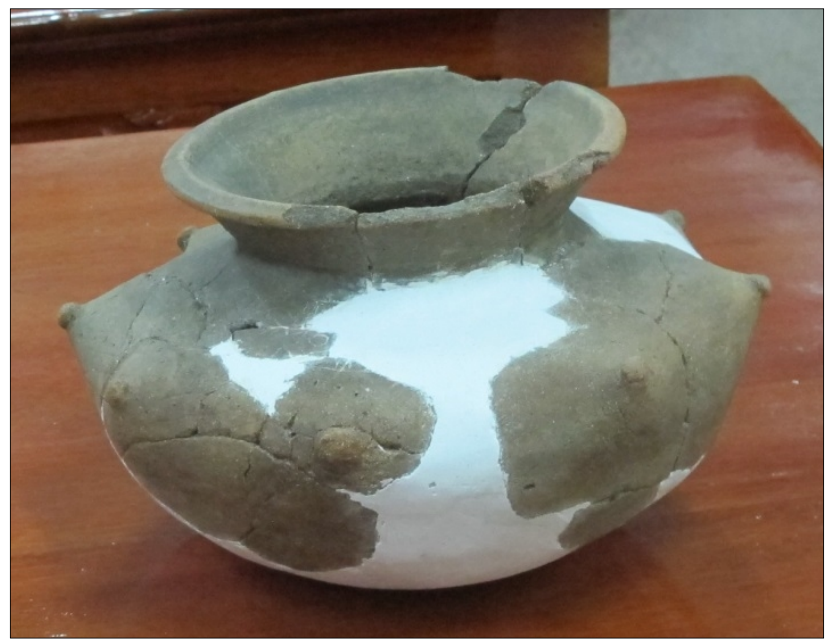

Figure 26: Vase with nipple motif, Hoa Diem site (central Vietnam).
The result of a long history of maritime contacts and trading were good opportunities for native inhabitants to adopt new knowledge, techniques and technologies. Meanwhile, demand for goods and raw materials, foods and other products resulted in the prosperity of local economies.

The "coastal polities" in southern Vietnam, as well in Southeast Asia were thus formed on the basis of cultural, social and commercial development, especially maritime trading and cultural interaction, which were reinforced by the ability of social organization influenced mainly from the idea and religious model of Indian civilization. Funan and Linyi were the first ones that have been testified by both archaeology and chronicles.

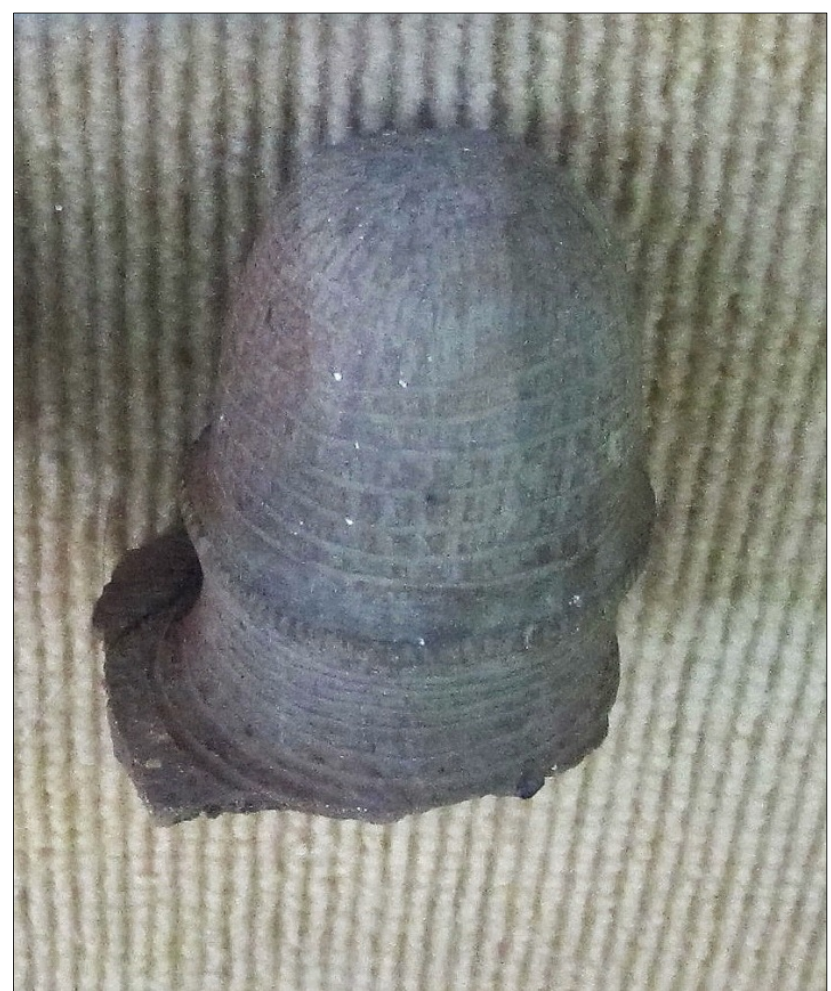

Figure 27: Phallic, terracotta, Long Thanh site (central Vietnam).

The context of the first penetration of Hindu beliefs in southern Vietnam was mainly through contact between coastal people and long-distance trading groups during the last centuries BC (in Can Gio area for example). From the coast, trading activities and cultural ideas most probably followed river systems, such as the Mekong, the Vam Co and the Dong Nai, to penetrate inland areas, such as the Long Xuyen quadrangular area (attested by Oc Eo, Nen Chua, and Nhon Thanh sites), the sand dunes between the rivers (Giong Noi site), the Dong Thap Muoi area (Go Thap site and Go Hang site), and the old alluvial terraced areas (Go Cao $\mathrm{Su}$ site) and further to southern Cambodia. According to comparative studies of unearthed artefacts, this process likely occurred during the last centuries $\mathrm{BC}$ and the first centuries $\mathrm{AD}$, as attested by the archaic form of Hindu symbols, the 'Siva trident for ex- 
ample, and the early type of Brahmi letters (Le 2006a: Ills. 225-227).

The period from the $2^{\text {nd }}-3^{\text {rd }}$ centuries to the $5^{\text {th }}$ century $A D$ witnessed a flourishing of trade activities, cultural interactions, and social development all over the lower Mekong river delta (including southern Vietnam and southern Cambodia), with the larger scale and number of sites and nature of unearthed artefacts. It is noteworthy that cultural influences from various areas of India can be identified. Contacts with Northwest India during the Kushana period are attested by the presence of a small Buddha head from Oc Eo and the beads from Go Hang (Malleret 1960: Pl. LXXXIV, 2; Bui et. al. 2001: 291, figs. 47, 49). Vestiges of Pallava and Gupta influence in art, religion, and inscriptions are among the most important evidence of cultural interaction during this period. The Pallava and the Gupta cultures clearly made great contributions to the development of major centers, in terms of economy, culture, and religion, and even politics in some cases, such as Oc Eo, Nen Chua, Da Noi, Nhon Thanh, and Go Thap. This was also a period of imitation followed by the formation of local art forms, as discussed above.

During the $6^{\text {th }}-7^{\text {th }}$ centuries, in addition to the localization of arts that represent regional characteristics, practices in religious ceremonies followed Indian texts but were probably modified as demonstrated by the consecrated deposits and architectural remains of temples distributed throughout the area. The same tendency occurred during the following period from the $8^{\text {th }}$ to about the $10^{\text {th }}$ century, although art and architecture declined and are not represented in great volume.

The decline of Oc Eo culture and the collapse of Funan in the late $7^{\text {th }}$ century, the shifting of maritime trade routes, temporary changes of the sea levels, and the formation of sand dunes along the rivers that blocked some areas might have created difficulties for direct and regular contacts with the outside world. Although religious practices continued, represented mainly by the development of several styles of art and architectures, simultaneous influences from Indian art and architecture are not seen obviously. New departures in styles of art and architecture can be observed, with the major sites shifting to northern Cambodia during the Chenla period (Briggs1951: 69-80).

\section{CONCLUSION}

Following the footsteps of traders and priests, Hinduism and other religions penetrated what is today southern $\mathrm{Vi}$ etnam at a very early time via pre-existing maritime network. Brahmanical, the 'Siva-Rudra and fertility cult in particular, were practiced by some groups in combination with local beliefs by the first centuries BC and AD. Following the development history of Indian religions and art, waves of cultural contacts and trading with various parts of the Indian sub-continent brought new ideas, knowledge and possibly skilled craftsmen to various parts of Southeast Asia, among which, southern Vietnam was the best place for settling. Indian Hindu theory its iconic canon contributed to the emerging of religious art and architecture in southern Vietnam, which were initiated in simple forms from the first half of the $1^{\text {st }}$ millennium $A D$ and developed local standardized styles during the $5^{\text {th }}$ $7^{\text {th }}$ centuries AD. Hindu beliefs were presented in various practices and ceremonies conducted by both the ruling class and the ordinary populace. The followers of 'Saivism, Viṣnuism, as well as Buddhism and probably others were co-living and providing patronage to religious events, particularly in trading centers and cities. The rulers might choose one or more specific gods and goddesses for their own during the devotional movement from the beginning of the $5^{\text {th }}$ century AD. This working hypothesis should be developed further by studying the written resource from the tiny artefacts, gold plaques found from temple consecrated deposits in particular. In that sense, evidence of Hinduism in southern Vietnam provides interesting information for the study of art, architecture, society, economy and politics of this area, as well as historical development and cultural exchanges and interactions among the maritime cultures and civilization of Asia and other parts of the world.

\section{ACKNOWLEDGEMENT}

This paper is partly the outcome of the research project "Study on Oc Eo culture and society - Analyses of archaeological evidence", which is financially supported by the NAFOSTED (National Foundation for Science and Technology Development, the Ministry of Science and Technology, Vietnam).The author would like to express special thanks to Prof. Michele Thompson and the editor of the JIPA for kindly help in English editing. My sincere thanks also go to the reviewers for their valuable critical comments and suggestions.

\section{REFERENCE}

Banerjea, J. N. 1974. The development of Hindu iconography. Delhi: Munshiram Manoharlal Publishers.

Bellina, B. 2003. Beads, social changes and interactions between India and Southeast Asia, Antiquity 77: 285-296.

Bellina, B. 2014. The development of Coastal Polities in the Upper Thai-Malay Peninsula, in Nicolas Revire \& Stephen A. Murphy (eds.), Before Siam - Essays in Art and Archaeology, pp. 68-89. Bangkok: River Books \& The Siam Society.

Bellina, B. and Glover, I. C. 2004. The archaeology of early contact with India and the Mediterranean world, from the fourth century BC to the fourth century AD. In I.C Glover and P. Bellwood (eds.), Southeast Asia from Prehistory to History, pp: 68-88. London: Routledge Curzon.

Borrel, B., Bellina, B., Chaisuwan, B. 2014. Contact between the Upper Thai-Malay Peninsula and the Mediterranean World, In Revire, N. \& Murphy S., A. (eds.), Before Siam, Essays in Art and Archaeology, pp. 98-117. Bangkok: River Books \& The Siam Society.

Bui, C. H. 2008. The Phu Chanh site: Cultural evolution and interaction in the later prehistory of Southern Vietnam, Bulletin of the Indo-Pacific Prehistory Association 28: 6772

Bui C. H., Dao, L. C. 2004. Khai quat Cat Tien, Lam Dong (Excavations at Cat Tien -Lam Dong), in Mot so van de ve 
khao co hoc o Mien Nam Viet Nam (Some Archaeological Achievements in Southern Vietnam] pp. 319-370. Hanoi: Social Publishing House.

Bui C. H., Pham, C. T., Nguyen K. T. K. 2012. Khao co hoc Ba Ria-Vung Tau - Tutiensu den so su [Archaeology in Ba Ria-Vung Tau province - from Prehistory to history], Social Publishing House, Ho Chi Minh City. Dao, L. C., 1995.Mo tang trong van hoa Oc Eo [Graves in Oc Eo Culture] PhD thesis, Document of the Institute of Archaeology.

Bui, P. D., Dao, L. C., Vuong, T. H. 2001. Khao co hoc Long An - Nhung the ky dau Cong nguyen [Archaeology in Long An Province - Centuries in early Christian Era], Long An: Long An Department of Culture and Information (in Vietnamese)

Briggs, L. P. 1951: The Ancient Khmer Empire. Philadelphia: American Philosophical Society,.

Dalsheimer, N., and Manguin, P. Y. 1998. "Visnumitrés et réseaux marchands en Asie du Sud-Est: Nouvelles données archéologiques sur le $\mathrm{I}^{\mathrm{er}}$ millénaire apr. J.-C." Bulletin de l'Ecole française d'Extrême Orient 85: 87-123.

Dao 1995: Mo tang trong van hoa Oc Eo [Graves in Oc Eo culture], unpublished PhD thesis. Hanoi: Library of Institute of Archaeology.

Dubois, A. J. A. 1936. Hindu manners, customs and ceremonies, Oxford: University Press.

Dupont, P. (1941), Vi'snu Mitrés de l'Indochine Occidentale, BEFEO 41: 233-254.

Dupont, P. 1955. La Statuaire Preangkorienne, Ascona.

Felten, W. and Lerner, M. 1988. Thai and Cambodian Sculpture, Klett-cotta, Stuttgart.

Glover, I. C. and Bellina, B. 2011. Ban Don Ta Phet and Khao Sam Kaeo: The earliest Indian contacts Re-assessed, in Early Indian influences in Southeast Asia: Reflection on Cross-cultural Movements, Edited by Pierre-Yves Manguin, A. Mani and Geoff Wade, Singapore, Manohar Publishers and distributors, 17-46.

Guy, John 2014. Lost Kingdoms - Hindu-Buddhist sculptures of Early Southeast Asia. New Haven and London: Yale University Press.

Ha. V. T. 1999. Khao co hoc Viet Nam [Vietnam Archaeology], Vol. II. Hanoi: Social Publishing House (in Vietnamese).

Hirano, Y. 2008. Regional trade and its development in the Iron Age of Vietnam: from the study of glass ornaments, $A r$ chaeology 3: 43-49.

Hung, H. C. \& Bellwood, P. 2010. Movement of raw materials and manufactured goods across the South China sea after 500 BCE: From Taiwan to Thailand and back, in (eds.) Bérénice Bellina, Elisabeth A. Bacus, Thomas Oliver Pryce \& Jan Wisseman-Christie, 50 Years of Archaeology in Southeast Asia-Essays in Honour of Ian Glover, pp. 234-245. Bangkok: River Books.

Imamura, K. 2006. The Distribution of Bronze Drums of the Heger I and Pre-I Types: Temporal Changes and Historical Background, paper presented at the $26^{\text {th }}$ Congress of the IPPA, Manila, 2006.

Indrawood, P. 2004. The Archaeology of the Early Buddhist Kingdoms of Thailand, In I.C Glover and P. Bellwood (eds.), Southeast Asia from Prehistory to History, pp: 120148. London: Routledge Curzon.
Krairiksh, P. 1980. Art in Peninsular Thailand Prior to the Fourteenth Century A.D., Bangkok: the Fine Art Department.

Lam, T. M. D. 2011. Central Vietnam during the Period from 500BCE to CE 500, in (eds) Pierre-Yves Manguin, A. Mani and Geoff Wade, Early Indian influences in Southeast Asia: Reflection on Cross-cultural Movements, pp. 316. Singapore: Manohar Publishers and distributors.

Lavy, P. A. 2003. As in Heaven, So on Earth: The Politics of Viṣnu, Siva and Harihara Images in Preangkorian Khmer Civilisation, Journal of Southeast Asian Studies 34:21-39.

Lavy, P. A. 2014. Conch-on-hip Images in Peninsular Thailand and Early Vaisnava Sculpture in Southeast Asia, in Nicolas Revire\& Stephen A. Murphy (eds.) Before Siam - Essays in Art and Archaeology, pp. 152-173. Bangkok: River Books \& The Siam Society.

Lê, D.P. 2006. Di tích Cát Tiên, Lâm Đồng - Lịchsửvà Vănhoá (Cat Tien site, Lam Dong province - History and Culture). Hanoi: Social Sciences Publishing House (in Vietnamese).

Lê, T. L. 2002. The Silk Road and the development of Buddhist and Hindu Sculpture in South Vietnam during the First 10 centuries A.D. Proceeding of UNESCO International Symposium on the Silk Roads in Commemoration of Completion of the Hirayama Silk Roads, pp: 134-143. Xian: Fellowships Program, Jiao Tong University.

Lê, T. L. 2005a. Gold Plaques and Their Archaeological Context in the Oc Eo culture. Bulletin of the Indo-Pacific Prehistory Association 25: 145-154.

Lê, T. L. 2005b. Di tich Go Thap va nhung van de cua van hoa Oc Eo [Go Thap site and the issues of Oc Eo culture], in Mot the kykhao co hoc Vietnam [One Century of Vietnam Archaeology], pp. 845-869. Hanoi: Social Publishing House.

Lê, T. L. 2006a. Buddhist \& Hindu Art in the Cuu Long River Delta Prior to $10^{\text {th }}$ Century AD. Hanoi: The Gioi Publishing House, (in Vietnamese).

Lê, T. L. 2006b. Excavations at Minh Su Mound, Go Thap site, Dong Thap province, South Vietnam, 2000-2003. In E. A. Bacus, I. C. Glover and V. C. Pigott (eds.), Uncovering Southeast Asia's Past, pp: 232-244. Singapore: NUS Press.

Lê, T. L. 2010. Buddhist Heritage: Archaeological evidence from Oc Eo culture (Southern Vietnam), in proceeding of the First International Conference on Buddhism Heritage in Southeast Asia, pp. 174-181. Phnom Penh.

Lê, T. L. 2011a. Hindu Deities in Southern Vietnam - Images Seen on the Tiny Archaeological Artefacts. In Manguin, P. Y., A. Mani \& Wade, G. (eds.), Early Indian influences in Southeast Asia: Reflection on Cross-cultural Movements, pp. 407-431. Singapore: Institute of Southeast Asian Studies.

Lê, T. L. 2011b. Metal ornaments and traces of their manufacturing in Oc Eo culture (Southern Vietnam), in Stephen C. and Barbara W. A. (eds.), Bujang Valley and Early Civilizations in Southeast Asia, pp: 299-309. Kuala Lumpur: Department of National Heritage, Ministry of Information, Communication and Cultures, Malaysia.

Lê, T. L. 2013. Brahmi inscription from archaeological sites in Southern Vietnam during the 1st millennium CE, paper presented in The First SEAMEO SPAFA International 
Conference on Southeast Asian Archaeology, 7 - 10 May 2013, Burapha University, Chonburi, Thailand.

Lê, T. L. 2014. Hindu-Buddhist Sculpture in Southern Vietnam: Evolution of Icons and Styles to the Eighth Century, in John Guy (ed.), in John Guy (ed.), Lost Kingdoms - Hindu-Buddhist Sculpture of Early Southeast Asia, pp. 118121. New Haven and London: Yale University Press.

Lê, T. L. and Nguyen T. B. T. 2010. Evidence of stone sculpture manufacturing from Go Thap site. New Discoveries in Archaeology of 2010, pp:751-752. Social Sciences Publishing House, Hanoi (in Vietnamese).

Lê, T. L, Ha, M. T., Nishimura, M. 2005. Baocaokhaiquat di chi cu truchan go Minh Su (Go Thap, Dong Thap) lanthuba [Report on the third excavation at Minh Su mound settlement site (Go Thap site complex, Dong Thap province)], Document at the Library of the Institute of Archaeology (in Vietnamese).

Lê, T. L. and Pham, L. H. 2003. Bao cao khai quat lan thu hai di chi cu truchan go Minh Su (khu di tich Go Thap, xa Tan Kieu, huyen Thap Muoi, tinh Dong Thap [Report on the second excavation at Minh Su mound settlement site (Go Thap site complex, Tan Kieu commune, Thap Muoi district, Dong Thap province)], Document at the Library of the Institute of Archaeology (in Vietnamese).

Lê, T. L. and Witzel, M. 2008. Contribution on the study of the golden metal artefacts found from Cat Tien, Lam Dong. Paper presented in the Third Conference on Cat Tien site, Da Lat, Lam Dong, December 2008.(in Vietnamese).

Lê, X. D., Dao, L. C. and Vo, S. Kh. 1995. Oc Eo Culture Recent Discoveries. Hanoi: Social Sciences Publishing House (in Vietnamese).

Malleret, L. 1959. L'archéologie du Delta du Mekong, T. I. Paris: EFEO.

Malleret, L. 1960. L'archéologie du Delta du Mekong, T. II. Paris: EFEO.

Malleret, L. 1962. L'archéologie du Delta du Mekong, T. III. Paris: EFEO.

Malleret, L. 1963. L'archéologie du Delta du Mekong, T. IV. Paris: EFEO.

Manguin, P. Y. 2002. Rapport Preliminaire Campagne Archéologique de Cooperation Franco-Vietnamiene. Mission Archéologie Du Delta Du Mekong 2002.

Manguin, P.-Y. 2004. The Archaeology of the Early Maritime polities of Southeast Asia, in P. Bellwood \& I. Glover (eds.), Southeast Asia: From prehistory to history, Curzon Press, Chap. 11, 282-313.

Manguin, P. Y. 2009. "The Archaeology of Funan in the Mekong River Delta: the Oc Eo Culture of Vietnam", in N. Tingley (ed.) Arts of Ancient Vietnam: From River Plain to Open Sea. New York, Houston: Asia Society, Museum of Fine Arts, Houston, Yale University Press, 2009, pp. $100-118$

Manguin, P. Y. 2010. Pan-regional Responses to South Asian inputs in Early Southeast Asia, in Bérénice Bellina, Elisabeth A. Bacus, Thomas Oliver Pryce \& Jan Wisseman Christie (eds.), 50 Years of Archaeology in Southeast Asia - Essays in Honour of Ian Glover, River Books, Bangkok. pp. 170-181.

Manguin, P. Y. \&Vo, S. K. 2000. Excavation at the Ba The/Oc Eo Complex (Vietnam) A Preliminary Report on the 1998 Campaign, Southeast Asian Archaeology 1998, Center for
Southeast Asian Studies, University of Hull, Great Britain, 107-121.

Miksic, J. N. 2003. Introduction: The Beginning of Trade in Ancient Southeast Asia: The Role of Oc Eo and the Lower Mekong River. In James C. M. Khoo (ed.), Art and Archaeology of Funan. Bangkok, Thailand.

Nguyen, D. T., Nguyen P. A. 1995. Nhung hien vat van hoa Oc Eo o bao tang tinh Can Tho [Artefacts of Oc Eo culture in Can Tho province museum], Can Tho province Museum (in Vietnamese).

Nguyen, K. D.; Glover, I., Yamagata, M.2006. Excavations at Tra Kieu and Go Cam, Quang Nam province, Central Vietnam, in E. A. Bacus, I. C. Glover and V. C. Pigott (eds.), Uncovering Southeast Asia's Past, pp: 216-231. Singapore: NUS Press.

Nguyen, T. H. 2004. Archaeological sites in the Can Gio saltmarsh area of Ho Chi Minh city. Một thế kỉ Khảo cổ học Việt Nam. Vol. I, pp: 874-93. Hanoi: Social Sciences Publishing House (in Vietnamese).

Nguyen, T. D. 2002. Khu di tich Cat Tien o Lam Dong [Cat Tien Complex site in Lam Dong province].Unpublished Ph.D. Thesis. Hanoi: Institute of Archaeology of Vietnam (in Vietnamese).

Nguyen, V. L., Ta T. K. O. and Masaaki T. 2000.Late Holocene depositional environments and coastal evolution of the Mekong River Delta, Southern Vietnam. Journal of Asian Earth Sciences 18: 427-439.

Nishimura, M. 2005. Chronology of the Metal Age in the southern Vietnam. Journal of Southeast Asian Archaeology 25: 105-147.

Nishimura, M. 2008. Bronze drums unearthed around the South China Sea and their cultural context. Vietnam Archaeology 3: 73-83.

Pelliot, P. 1903. Le Founan, BEFEO III: 248-303. Document of the Institute of Archaeology (Vietnamese translated version).

Pham, N., H. and Le, Thi Lien 2001. Bao cao khai quat di chi cu tru Chan go Minh Su - Di tich Go Thap [Report on the excavation at Minh Su mound settlement site - Go Thap site]. Hanoi: Library of the Institute of Archaeology (in Vietnamese).

Pham, Nhu Ho, Nguyen, T., D. 1995: Khai quat khu phet ich thap co duoi chan Thap Binh Thanh (Tay Ninh) [Excavation of ancient tower remain complex at the foot of Binh Thanh tower], in New Discoveries in Archaeology of 1994, pp. 414-416. Hanoi: Social Publishing House (in Vietnamese).

Rajan, K. 2011. Emergence of Early Historic Trade in Peninsular India. In Manguin, P. Y., A. Mani \& Wade, G. (eds.), Early Indian influences in Southeast Asia: Reflection on Cross-cultural Movements. Singapore: Institute of Southeast Asian Studies.

Ray, H. P. 2014. Multi-religious Maritime Linkages across the Bay of Bengal during the First Millennium CE, in Nicolas Revire\& Stephen A. Murphy (eds.) Before Siam - Essays in Art and Archaeology, pp. 135-151. Bangkok: River Books \& The Siam Society.

Reinecke, A., Vin Laychour, Seng Sonetra 2009. The First Golden Age of Cambodia: Excavation at Prohear, Bonn.

Ślączka, A. A. 2007. Temple Consecration Rituals in ancient India - Text and Archaeology, Brill, Leiden . Boston. 
Ślączka, A. A. 2011. The brick structures of Go Thap - tombs or temples? Bulletin of the Indo Pacific Prehistory Association 31: 108-116.

Stark, M. T. 1998. The Transition to History in the Mekong Delta: A View from Cambodia, International Journal of Historical Archaeology 2: 175-203.

Stark, M. T. 2001. Some preliminary Results of the 1999-2000 Archaeological Field Investigations at Angkor Borei, Takeo province. Udaya: Journal of Khmer Studies 1: 1936.

Stark, M. T. 2003. Angkor Borei and the Archaeology of Cambodia's Mekong Delta, in James C.M. Khoo (ed.), Art and Archaeology of Funan, pp. 87-106. Bangkok: Orchid Press.

Stark, M. T. 2004. Pre-Angkorian and Angkorian Cambodia, in Ian Glover and Peter Bellwood (eds.), Southeast Asia from prehistory to history, pp. 89-119. London and New York: Routledge Curzon.

Stark, M. T. 2006. Pre-Angkorian settlement trends in Cambodia's Mekong delta and the lower Mekong archaeological project. Bulletin of the Indo Pacific Prehistory Association 26: 98-109.

Stark, M. T., Sanderson, D., Bingham, R. G. 2006. Monumentality in the Mekong delta: Luminescence dating and implications. Bulletin of the Indo Pacific Prehistory Association 26: 110-120.

Thapar, R. 1992. A History of India, Vol. One, Calcutta: Penguin Books.

Trần, A. D., Bùi, V. L. and Nguyễn, Đ. C. 1999. Report on the excavation in Cao Su Mound site (Long An province). Hanoi: Institute of Archaeology (in Vietnamese).

Trần, A. D. and Lại, V. T. 2007. The three excavations at Giong Noi site (Ben Tre province). Khao co hoc 2 (146): 13-35 (in Vietnamese).

Tran, Q. T., Nguyen, T., Nguyen, N. Q. 2012: Di chi khao co hoc Vinh Yen, Khanh Hoa [Vinh Yen Archaeological Site, Khanh Hoa province], Lao Dong Publishing House (in Vietnamese).

Trịnh, H. Đ. 1998. Gia Định thàn hthông chí.Translation version of Institute of History. Education Publishing House, Hanoi. (in Vietnamese).

Trongjai, H. 2014. Reconsidering the Paleo-shoreline in the Lowe Central Plain of Thailand, in Nicolas Revire\& Stephen A. Murphy (eds.) Before Siam - Essays in Art and Archaeology, pp. 32-67. Bangkok: River Books and The Siam Society.

Vo, S. K. 2003. The kingdom of Funan and the culture of Oc Eo. In James C. M. Khoo (ed.), Art and Archaeology of $\mathrm{Fu}$ nan. Bangkok, Orchid Press.

Yamagata, M. 2006. Inland Sa Huynh culture along the Thu Bon river valley in Central Vietnam, in E. A. Bacus, I. C. Glover and V. C. Pigott (eds.), Uncovering Southeast Asia's Past, pp. 168-183. Singapore, NUS Press.

Witzel, M. and Lê, T. L. 2007.Gop them thong tin tu cac manh vang cua Go $6 B$ (Cat Tien, Lam Dong) [More information from the gold plaques of Go 6B (Cat Tien site, Lam Dong province)], NPHMVKCH nam 2007, pp: 685-687. Hanoi: Tudien Bach Khoa Publishing House (in Vietnamese). 